\section{Special Report 84-6}

April 1984

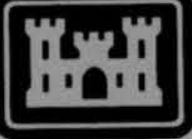

US Army Corps of Engineers

Cold Regions Research \& Engineering Laboratory

\title{
Model tests in ice of a Canadian Coast Guard $R$-class icebreaker
}

Jean-Claude Tatinclaux 


\begin{tabular}{|c|c|c|}
\hline \multicolumn{2}{|c|}{ REPORT DOCUMENTATION PAGE } & \multirow{2}{*}{\begin{tabular}{|c|c|} 
& READ INSTRUCTIONS \\
& BEFORE COMPLETING FORM \\
3. RECIPIENT'S CATALOG NUMBER
\end{tabular}} \\
\hline $\begin{array}{l}\text { 1. REPORT NUMBER } \\
\text { Special Repo }\end{array}$ & 2. GOVT ACCESSION NO. & \\
\hline \multirow{2}{*}{\multicolumn{2}{|c|}{$\begin{array}{l}\text { 4. TITLE (and Subtitle) } \\
\text { MODEL TESTS IN ICE OF A CANADIAN } \\
\text { COAST GUARD R-CLASS ICEBREAKER }\end{array}$}} & 5. TYPE OF REPORT \& PERIOD COVERED \\
\hline & & 6. PERFORMING ORG. REPORT NUMBER \\
\hline \multirow{2}{*}{\multicolumn{2}{|c|}{$\begin{array}{l}\text { 7. AUTHOR(s) } \\
\text { Jean-Claude Tatinclaux }\end{array}$}} & 8. CONTRACT OR GRANT NUMBER(s) \\
\hline & & $\begin{array}{l}\text { 10. PROGRAM ELEMENT, PROJECT, TASK } \\
\text { AREA \& WORK UNIT'NUMBERS }\end{array}$ \\
\hline \multirow{2}{*}{\multicolumn{2}{|c|}{$\begin{array}{l}\text { 11. CONTROLLING OFFICE NAME AND ADDRESS } \\
\text { U.S. Army Cold Regions Research and } \\
\text { Engineering Laboratory } \\
\text { Hanover, New Hampshire } 03755\end{array}$}} & $\begin{array}{l}\text { 12. REPORT DATE } \\
\text { April } 1984\end{array}$ \\
\hline & & $\begin{array}{l}\text { 13. NUMBER OF PAGES } \\
31\end{array}$ \\
\hline \multirow{2}{*}{\multicolumn{2}{|c|}{ 14. MONITORING AGENCY NAME \& ADDRESS(if different from Controlling Office) }} & $\begin{array}{l}\text { 15. SECURITY CLASS. (of this roport) } \\
\text { Unclassified }\end{array}$ \\
\hline & & $\begin{array}{l}\text { 15a. DECLASSIFICATION/DOWNGRADING } \\
\text { SCHEDULE }\end{array}$ \\
\hline \multicolumn{3}{|c|}{$\begin{array}{l}\text { 16. DISTRIBUTION STATEMENT (of this Report) } \\
\text { Approved for public release; distribution unlimited. }\end{array}$} \\
\hline \multicolumn{3}{|c|}{ 17. DISTRIBUTION STATEMENT (of the abstract ontered in Block 20, if different from Report) } \\
\hline \multicolumn{3}{|c|}{ 18. SUPPLEMENTARY NOTES } \\
\hline \multicolumn{3}{|c|}{\begin{tabular}{ll|} 
19. KEY WORDS (Continue on reverse side if necessary and identify by block number) \\
Brash ice & Model icebreakers \\
Ice & Model tests \\
Icebreakers & Propulsion tests \\
Level ice & Resistance tests \\
Model basins & \\
\end{tabular}} \\
\hline \multicolumn{3}{|c|}{$\begin{array}{l}\text { 20. ABSTRACT (Continue an revers sidn necosary and fontify by block number) } \\
\text { This report presents the results of resistance and propulsion tests in level ice } \\
\text { of a } 1: 20-\mathrm{scale} \text { model of the R-class icebreaker of the Canadian Coast Guard. } \\
\text { On the basis of the model test results, full-scale performance is predicted and } \\
\text { compared with available full-scale trials data. Predicted ice resistance and } \\
\text { required propeller rpm, thrust and delivered power are lower than full-scale } \\
\text { measurements. This disagreement was attributed to the fact that the ship model } \\
\text { had a much lower ice friction coefficient than the prototype. On the other }\end{array}$} \\
\hline
\end{tabular}




\section{Abstract (cont'd)}

hand, predictions of thrust and power for a given ship speed and propeller rpm are in good agreement with corresponding full-scale measurements. 


\section{PREFACE}

This report was prepared by Dr. Jean-Claude Tatinclaux, Research Hydraulic Engineer, of the Ice Engineering Research Branch, Experimental Engineering Division, U.S. Army Cold Regions Research and Engineering Laboratory. This study was CRREL's contribution to an international project proposed by the Committee on Ships in Ice Covered Waters at the 16th International Towing Tank Conference.

This report was technically reviewed by Dr. George D. Ashton (CRREL) and Dr. Hung T. Shen (Clarkson College, Potsdam, N.Y.).

The contents of this report are not to be used for advertising or promotional purposes. Citation of brand names does not constitute an official endorsement of approval of the use of such commercial products. 
CONTENTS

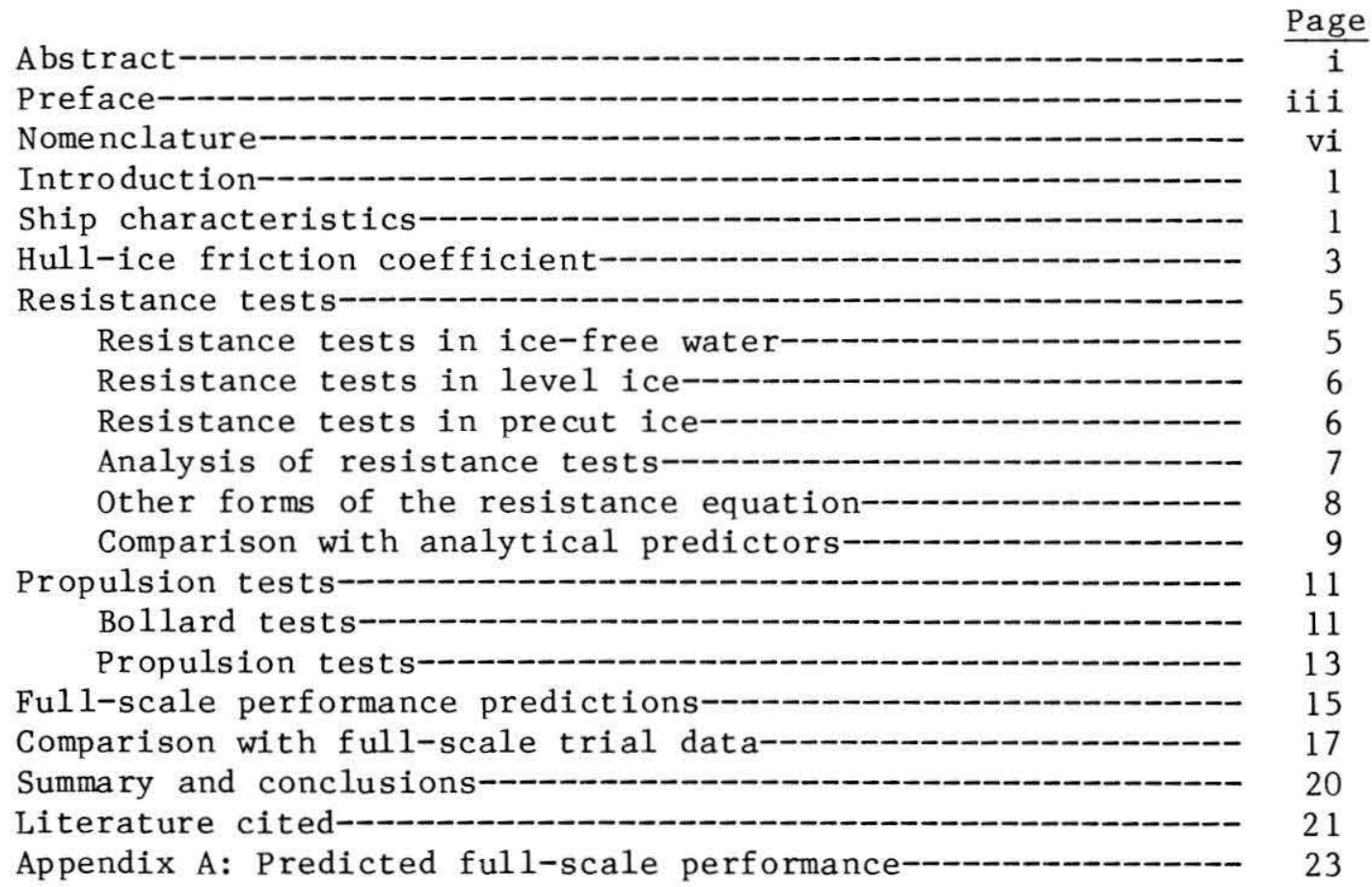

\section{ILLUSTRATIONS}

Figure

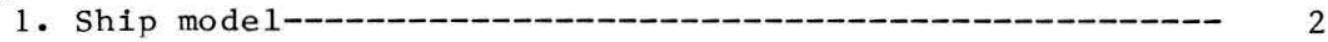

2. Model resistance in ice-free water------------------- 5

3. Comparison between ice resistance measurements and predictions by Kashtelyan and Carter-------------- 10

4. Comparison between ice resistance measurements and predictions by Carter-- 10

5. Comparison of pull force measured in forward bollard tests at CRREL and NRCC---- 11

6. Thrust and torque coefficients in level ice versus apparent advance coefficient------------------------ 14

7. Model total thrust versus model total resistance in level ice at self-propulsion points--- 15

8. Predicted ful1-scale performance--- 16

9. Predicted versus measured full-scale performance------- 18

10. Calculated versus measured thrust and power at fullscale speed and propeller rpm----- 
TABLES

Table

1. Principal particulars of hull and propellers---------

2. Results of friction tests----

3. Results of resistance tests in ice-free water--_-_-_---

4. Results of resistance tests in level ice-------------- 7

5. Results of resistance tests in precut ice------------ 7

6. Results of forward bollard tests--_---_---_--- 12

7. Results of propulsion tests in level ice------------ 13

8. Calculated self-propulsion points------------ 14

9. Calculated versus measured ful1-scale performance------ 18

10. Calculated and measured thrust and power at full-

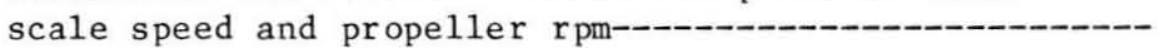




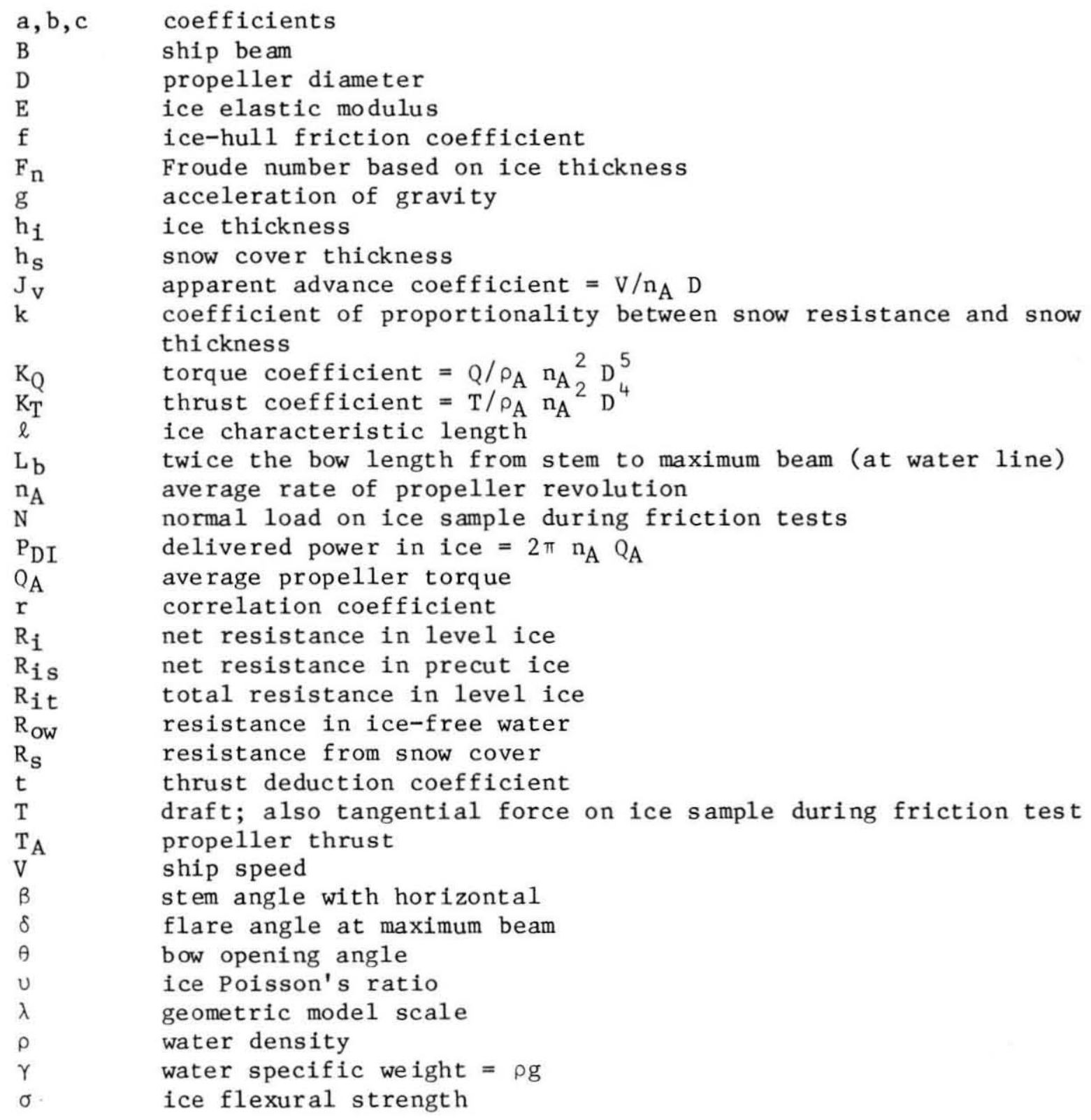


MODEL TESTS IN ICE OF A CANADIAN COAST GUARD R-CLASS ICEBREAKER

J.C. Tatinclaux

\section{INTRODUCTION}

The Committee on Ships in Ice-Covered Waters of the International Towing Tank Conference (ITTC), of which the U.S. Army Cold Regions Research and Engineering Laboratory (CRREL) is a member organization, developed a test program for an icebreaker model to be carried out by all organizations possessing ice model basins willing and able to participate in this international program. The test program was outlined in the Committee Report to the 16th ITTC (Committee on Ships in Ice-Covered Waters 1981). The test results obtained by the participating organizations were to be gathered and analyzed by Dr. R.V. Milano for presentation at the 17 th ITTC in September 1984 in Goteborg, Sweden. The icebreaker model selected by the Committee was that of the most recent Canadian R-class icebreaker and was provided by the National Research Council of Canada (NRCC). Two model scales were chosen, namely $1: 20$ and 1:40. Resistance and propulsion tests were to be carried out with the 1:20-scale mode1 in those ice test basins large enough to accommodate models of that size. Other tanks were to host only resistance tests on the 1:40scale model since propulsion tests for such a small model would not produce meaningful results.

This report presents the results of the resistance and propulsion tests performed at CRREL with a $1: 20$-scale model.

\section{SHIP CHARACTERISTICS}

The Canadian Coast Guard is operating two R-class icebreakers, the CCGS Radisson and the CCGS Franklin. Mode1 tests were made both in ice-free water (Murdey 1980) and in ice (Noble and Bulat 1979). Field trials were also carried out with both icebreakers (Edwards et al. 1981, Michailidis and Murdey 1981).

The R-class icebreaker is designed to break continuously through $1 \mathrm{~m}$ ( 3 $\mathrm{ft}$ ) of level ice. The ship has a displacement of approximately 8000 tons at 


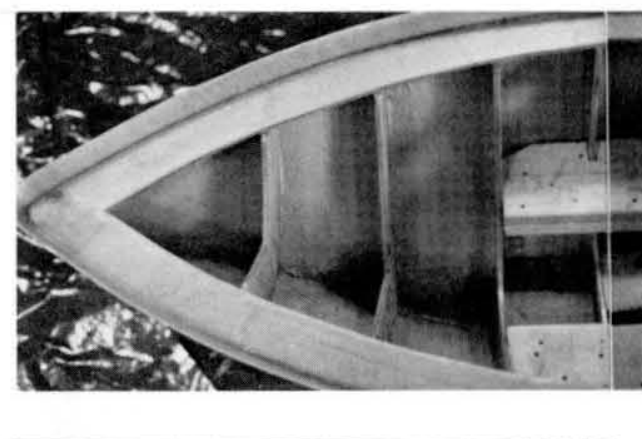

$32 \pi-2$
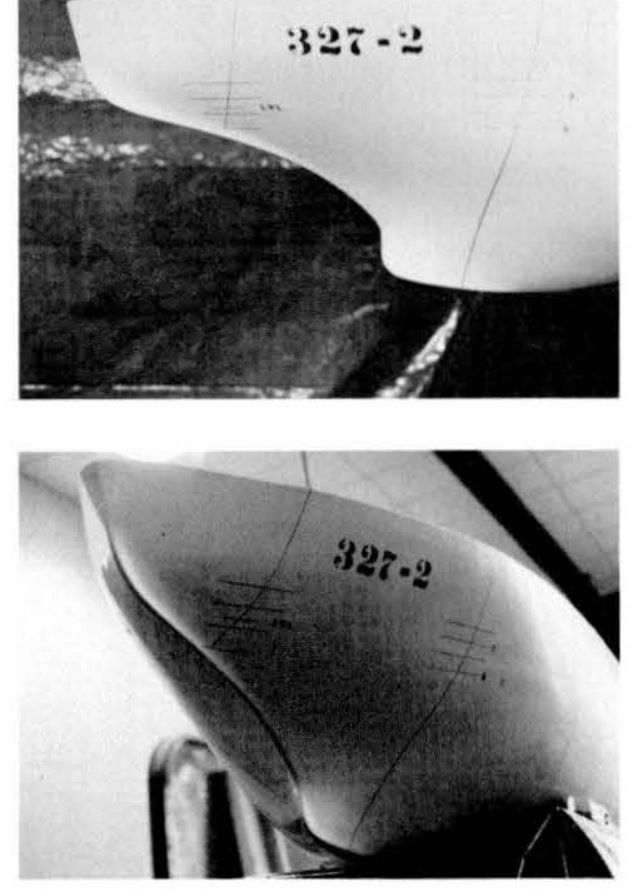

FOREBODY

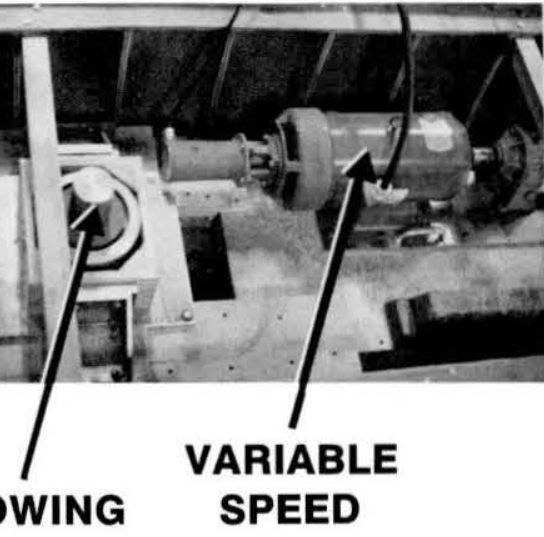

POST
SPEED MOTOR
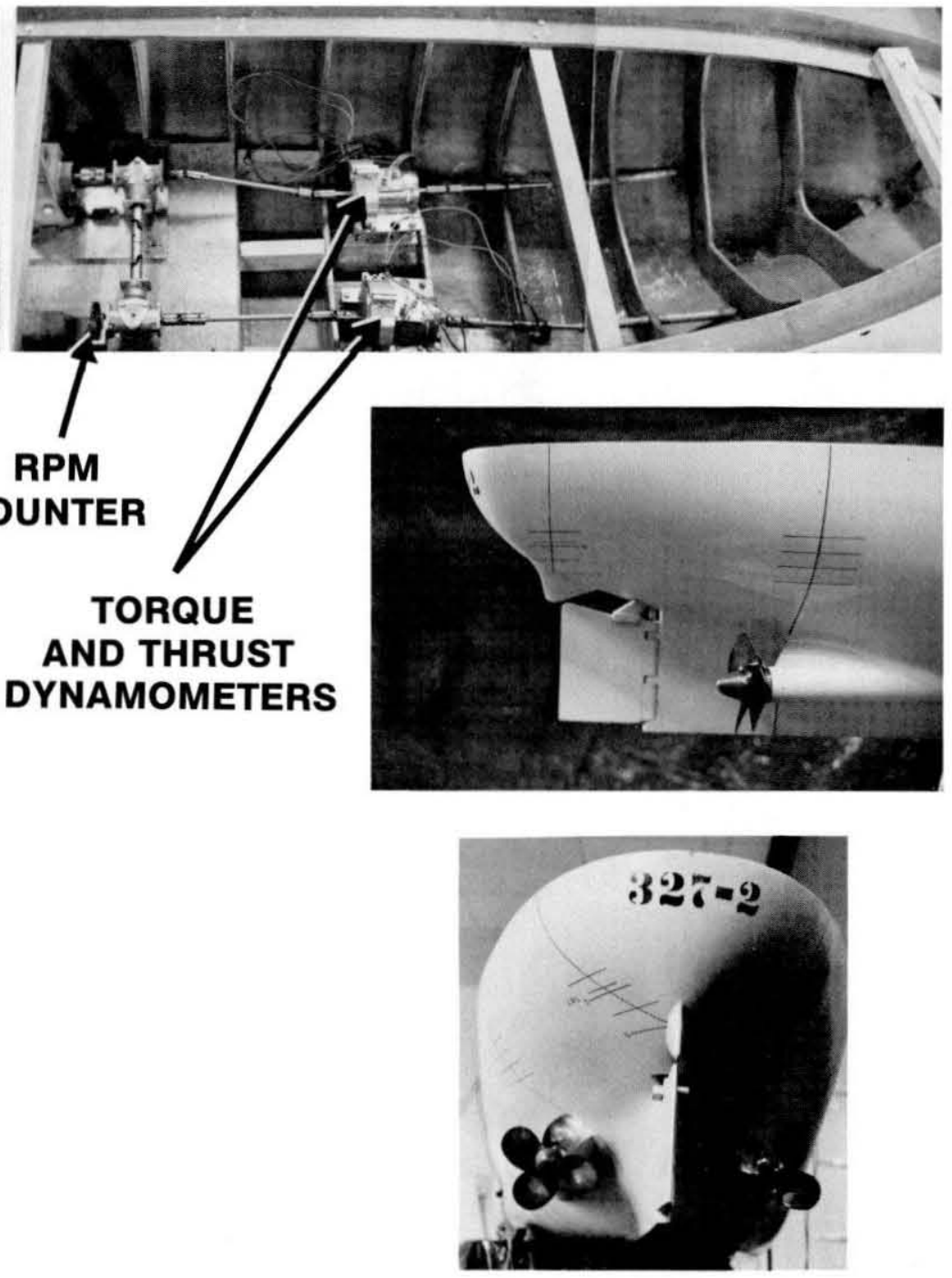

AFTBODY 
Table 1. Principal particulars of hull and propellers.

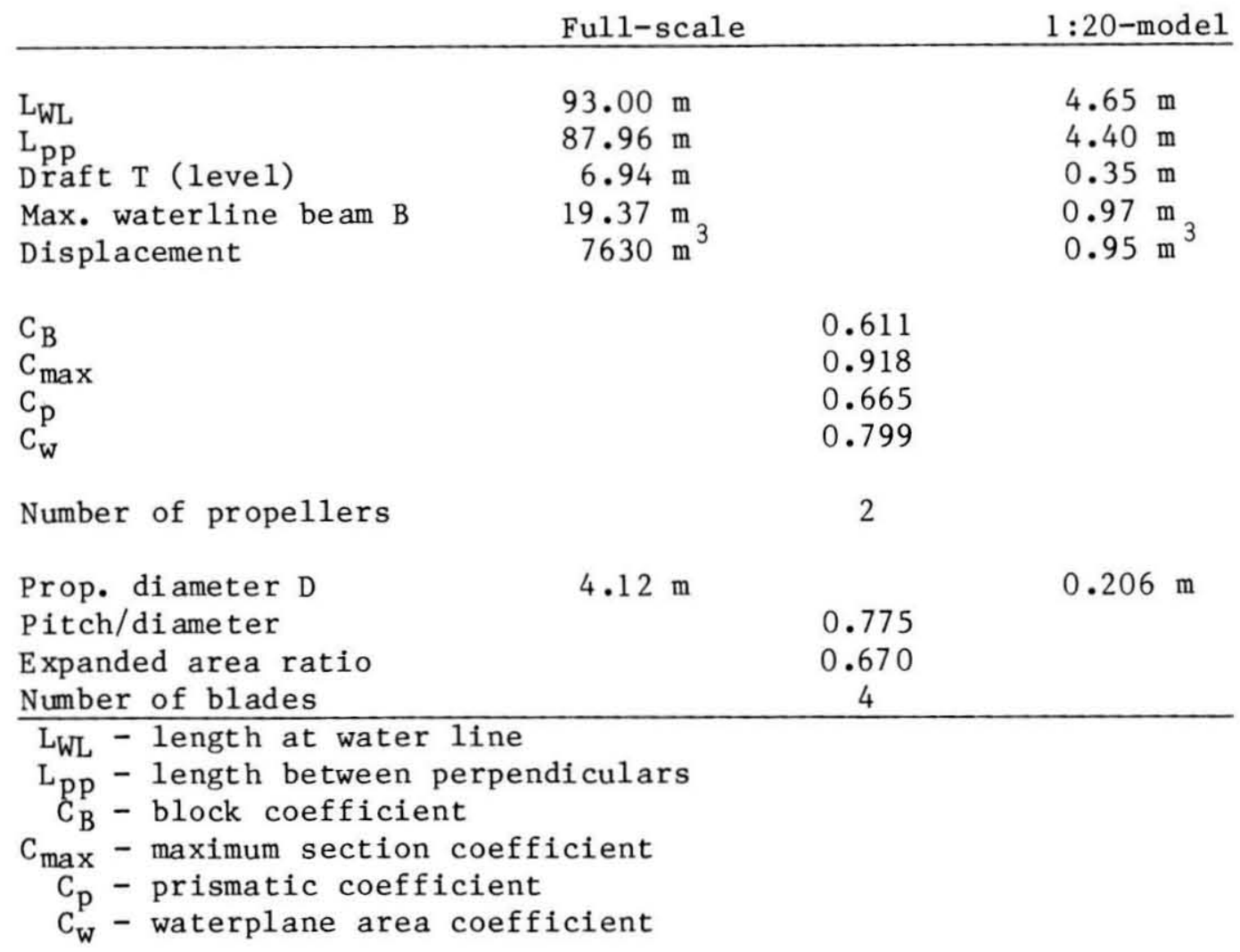

a midship draft of $6.9 \mathrm{~m}$ and is propelled by twin fixed-pitch propellers with a total shaft power of $11,000 \mathrm{~kW}$.

The main hull and propeller characteristics of the ship are listed in Table 1 for both the full-scale size and the 1:20-scale model. Photographs of the model are shown in Figure 1.

\section{HULL-ICE FRICTION COEFFICIENT}

For determining the friction coefficient between ice and the ship model hul1, NRCC had provided a flat board with the same surface finish as the hull.

A 20- by $20-\mathrm{cm}$ ice sample cut from the ice sheet in the test basin was loaded with a total weight of $725 \mathrm{~N}(163 \mathrm{1b})$ and dragged over the board at a constant speed of $8 \mathrm{~cm} / \mathrm{s}$, approximately, by a linear actuator. The friction force was measured by a 44-N (10-1b) load cell connecting the actuator rod and the ice sample holder. The top and bottom surfaces of the ice were tested under both dry and wet conditions. 
The results of the friction measurements are listed in Table 2. As can be seen from the data, the friction coefficient was practically independent of ice surface (top or bottom) and test conditions (dry or wet), with an overall average value of

$$
\mathrm{f}=0.041 \pm 0.004 \text {. }
$$

It should be noted that this $\mathrm{f}$-value for the model is extremely 1 ow because of the very smooth surfaces of the fiber glass ship's hull and test board. The full-scale ship is likely to have a higher friction factor. Edwards et a1. (1981) gave friction factors of 0.30 at low speed and 0.19 at high speed. No values were reported by Michailidis and Murdey (1981).

Table 2. Results of friction tests.

\begin{tabular}{|c|c|c|c|c|}
\hline Test conditions & $\begin{array}{l}\text { Norma } 1 \\
\text { Force N } \\
(\mathrm{N})\end{array}$ & $\begin{array}{c}\text { Tangential } \\
\text { Force T } \\
(\mathrm{N})\end{array}$ & $\mathrm{f}=\mathrm{T} / \mathrm{N}$ & Average $\mathrm{f}$ \\
\hline Ice top dry & $\begin{array}{l}725.00 \\
725.00 \\
725.00 \\
725.00 \\
725.00 \\
725.00\end{array}$ & $\begin{array}{l}30.51 \\
24.60 \\
29.71 \\
27.85 \\
33.94 \\
32.34\end{array}$ & $\begin{array}{l}0.042 \\
0.034 \\
0.041 \\
0.038 \\
0.047 \\
0.045\end{array}$ & $0.041 \pm 0.005$ \\
\hline Ice bottom dry & $\begin{array}{l}725.00 \\
725.00 \\
725.00 \\
725.00 \\
725.00 \\
725.00\end{array}$ & $\begin{array}{l}28.20 \\
30.34 \\
32.92 \\
32.92 \\
33.98 \\
31.94\end{array}$ & $\begin{array}{l}0.039 \\
0.042 \\
0.045 \\
0.045 \\
0.047 \\
0.044\end{array}$ & $0.044 \pm 0.003$ \\
\hline Ice top wet & $\begin{array}{l}725.00 \\
725.00 \\
725.00 \\
725.00 \\
725.00 \\
725.00\end{array}$ & $\begin{array}{l}27.49 \\
29.22 \\
34.30 \\
34.07 \\
31.72 \\
30.56\end{array}$ & $\begin{array}{l}0.038 \\
0.040 \\
0.047 \\
0.047 \\
0.044 \\
0.042\end{array}$ & $0.043 \pm 0.004$ \\
\hline Ice bottom wet & $\begin{array}{l}725.00 \\
725.00 \\
725.00 \\
725.00 \\
725.00 \\
725.00 \\
\end{array}$ & $\begin{array}{l}24.55 \\
27.05 \\
27.13 \\
28.07 \\
28.11 \\
29.85 \\
\end{array}$ & $\begin{array}{l}0.034 \\
0.037 \\
0.037 \\
0.039 \\
0.039 \\
0.041 \\
\end{array}$ & $0.038 \pm 0.002$ \\
\hline
\end{tabular}


RESISTANCE TESTS

Resistance tests in ice-free water

For comparison with the open

water resistance tests made at NRCC, as well as for aiding later analysis of the tests in level ice, a series of resistance tests were run in icefree water over the range of velocities to be used in the ice tests.

The results of the open water resistance tests are listed in Table 3 and shown graphically in Figure 2, where both the CRREL data and NRCC data are presented. The NRCC data were calculated from the results presented by Murdey (1980), adjusted to a water temperature of $0^{\circ} \mathrm{C}$. The CRREL data are, in the average, 20\% larger than those measured at NRCC.

In the CRREL tests the ship model was equipped with the two propellers, while fairing cones were fitted to the bossings in the NRCC tests. In addition the tripwires used as turbulence stimulators in the NRCC resistance tests were not fitted to the model during the CRREL ice-free resistance tests since they would have severely interfered with the following resistance tests in ice. For those reasons the CRREL results were expected to be higher than those obtained at NRCC.

It should also be mentioned that the towing and load measurement apparatus of the CRREL test basin are designed for ice loads that are usually significantly higher than those measured in ice-free resistance tests, and that the accuracy of the measurements is on the order of $\pm 5 \mathrm{~N}$.

For use in later analysis, the CRREL data were fitted by the following relationship tests in ice-free water.

\begin{tabular}{crr}
$V$ & \multicolumn{2}{c}{ Resistance $(\mathrm{N}) *$} \\
\cline { 2 - 3 }$(\mathrm{m} / \mathrm{s})$ & CRREL & NRC \\
\hline & & \\
0.68 & 4.89 & 7.22 \\
0.77 & 11.03 & 8.82 \\
0.88 & 1437 & 11.30 \\
1.01 & 14.59 & 14.42 \\
1.05 & 18.82 & 15.59 \\
1.14 & 15.57 & 18.27 \\
1.26 & 31.36 & 22.33 \\
1.30 & 33.23 & 23.56 \\
1.36 & 34.96 & 25.51 \\
1.38 & 36.83 & 26.58 \\
1.49 & 39.72 & 32.13 \\
1.61 & 54.00 & 38.20 \\
1.73 & 60.10 & 47.20 \\
* Resistance measured in CRREL ice \\
basin and resistance measured at \\
NRCC.
\end{tabular}

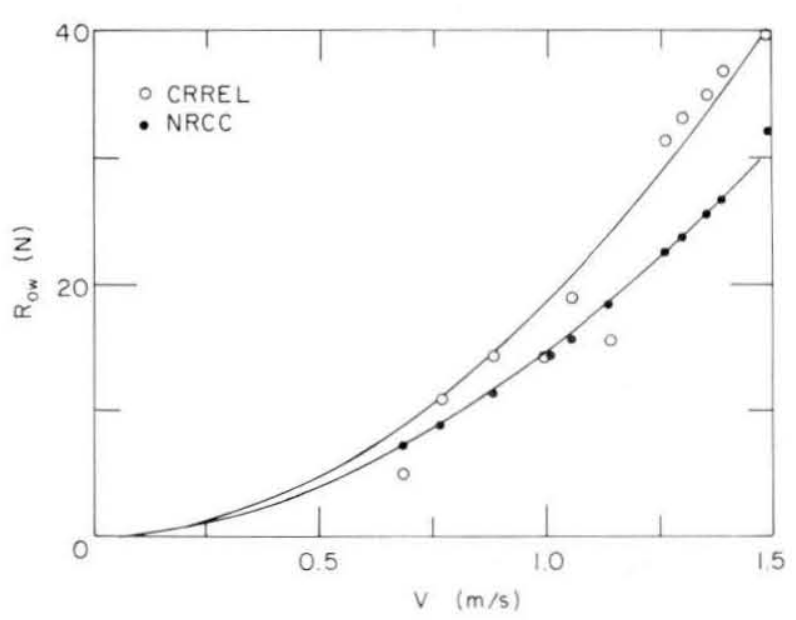

Figure 2. Mode1 resistance in icefree water.
Table 3. Results of resistance 


$$
\mathrm{R}_{\mathrm{ow}}=18.73 \mathrm{v}^{1.93}
$$

in which $\mathrm{R}_{\text {ow }}$ (resistance in ice-free water) is expressed in $\mathrm{N}$ and $\mathrm{V}$ ( $\operatorname{ship}$ speed) in $\mathrm{m} / \mathrm{s}$.

Resistance tests in leve1 ice

The ITTC test program called for tests in full-scale ice thicknesses of 70 and $45 \mathrm{~cm}$, corresponding to model ice thicknesses of 3.5 and $2.25 \mathrm{~cm}$ for the 1:20-scale model, and full-scale ice flexural strengths of 800 and 400 $\mathrm{kPa}, 40$ and $20 \mathrm{kPa}$ for the model. The ship velocities to be investigated were $0.5,1.5$ and $2.5 \mathrm{~m} / \mathrm{s}$ at full scale $(0.11,0.34$ and $0.56 \mathrm{~m} / \mathrm{s}$ at mode 1 scale) for the stronger ice and $0.5,2.5$ and $5.5 \mathrm{~m} / \mathrm{s}$ at full scale $(0.11$, 0.56 and $1.23 \mathrm{~m} / \mathrm{s}$ at model scale) for the weaker ice.

The actual range of parameters tested were 2 to $4 \mathrm{~cm}$ for ice thickness, 25 to $50 \mathrm{kPa}$ for ice flexural strength and 0.11 to $1.3 \mathrm{~m} / \mathrm{s}$ for the velocity. The ice thickness was measured with a precision caliper. The ice flexural strength was obtained from in-situ tests of small cantilever beams. The beams were cut with a length of 7 to 10 times the ice thickness and a width 1.5 to 2 times the thickness. The load was applied downward at the tip of the beams by a hand-held Chatillon push-pull gauge. The elastic modulus $\mathrm{E}$ of the ice was measured by the plate deflection method.

A total of 20 tests were run; the test conditions and results are listed in Table 4. The net ice resistance $R_{i}$ was calculated as the difference between the measured total resistance $R_{i t}$ and the ice-free resistance $R_{\text {ow }}$ obtained from Figure 2. In ice resistance tests, the open water resistance is of ten considered negligible as compared to the ice resistance; however, in the present tests at the higher velocities ( $1 \mathrm{~m} / \mathrm{s}$ or more, model scale), the open water resistance could be as high as $25-30 \%$ of the total resistance and could not be neglected.

\section{Resistance tests in precut ice}

In an attempt to differentiate among the various components of the level ice resistance of a given ship hull, tests were also run through precut ice. In the tests, a channel of width only slightly larger than the maximum beam of the model was hand sawed in the level ice sheet. The ice within this channel was cut into more or less regular pieces of average size similar to that which had been observed in the track left by the ship during the resistance tests through level ice. Six such tests were run for the range of ve- 
Table 4. Results of resistance tests in level ice.

\begin{tabular}{|c|c|c|c|c|c|c|}
\hline $\begin{array}{c}\mathrm{V} \\
(\mathrm{m} / \mathrm{s})\end{array}$ & $\begin{array}{c}\mathrm{h}_{\mathrm{i}} \\
(\mathrm{cm})\end{array}$ & $\begin{array}{c}\sigma \\
(\mathrm{kPa})\end{array}$ & $\begin{array}{c}E \\
(\mathrm{MPa})\end{array}$ & $\begin{array}{l}\mathrm{R}_{\mathrm{it}}{ }^{*} \\
(\mathrm{~N})\end{array}$ & $\begin{array}{c}\mathrm{R}_{\mathrm{OW}}^{\dagger} \\
(\mathrm{N})\end{array}$ & $\begin{array}{l}\mathrm{R}_{\mathrm{i}}{ }^{* *} \\
(\mathrm{~N})\end{array}$ \\
\hline 0.13 & 2.84 & 47.00 & 94.00 & 57.00 & 0.00 & 57.00 \\
\hline 0.38 & 3.00 & 47.00 & 94.00 & 67.75 & 3.50 & 64.25 \\
\hline 0.35 & 3.12 & 55.00 & 40.00 & 89.00 & 3.00 & 86.00 \\
\hline 0.62 & 3.55 & 50.00 & 40.00 & 96.10 & 7.20 & 88.90 \\
\hline 0.13 & 3.72 & 45.00 & 40.00 & 75.20 & 0.00 & 75.20 \\
\hline 0.13 & 3.61 & 25.00 & 32.00 & 32.10 & 0.00 & 32.10 \\
\hline 0.62 & 3.66 & 25.00 & 32.00 & 64.50 & 7.20 & 57.30 \\
\hline 0.37 & 4.00 & 25.00 & 32.00 & 49.80 & 3.30 & 46.50 \\
\hline 0.11 & 2.06 & 39.00 & 33.00 & 23.30 & 0.00 & 23.30 \\
\hline 1.31 & 2.15 & 55.00 & 35.00 & 113.90 & 32.00 & 81.90 \\
\hline 0.59 & 2.25 & 47.00 & 33.00 & 51.60 & 6.60 & 45.00 \\
\hline 0.12 & 2.15 & 30.00 & 33.00 & 21.40 & 0.00 & 21.40 \\
\hline 1.19 & 2.27 & 45.00 & 33.00 & 99.20 & 26.00 & 73.20 \\
\hline 0.60 & 2.41 & 38.00 & 33.00 & 45.40 & 6.80 & 38.60 \\
\hline 0.11 & 2.15 & 26.00 & 25.00 & 25.80 & 0.00 & 25.80 \\
\hline 0.57 & 2.33 & 30.00 & 25.00 & 48.00 & 6.40 & 41.60 \\
\hline 1.28 & 2.46 & 35.00 & 25.00 & 98.30 & 30.00 & 68.30 \\
\hline 0.11 & 3.54 & 25.00 & 30.00 & 32.80 & 0.00 & 32.80 \\
\hline 0.33 & 3.78 & 30.00 & 30.00 & 60.20 & 2.90 & 57.30 \\
\hline 0.56 & 3.96 & 34.00 & 30.00 & 73.70 & 6.00 & 67.70 \\
\hline
\end{tabular}

locity and ice thickness investigated in the level ice test. The corresponding data are listed in Table 5 .

\section{Analysis of resistance tests}

In the tests through precut ice, the ice resistance $R_{i s}$ should be a function of only the ice thickness $h_{i}$ and ship speed $v$. Dimenensional analysis indicates that the dimensionless resistance $\mathrm{R}_{i s} / \gamma B h_{i}{ }^{2}$, with $\gamma=$ specific weight of water and $B=$ ship beam, should be only a function of the Froude number $F_{n}=V / \sqrt{g h_{i}}$. Regression analysis of the data yielded

$$
\frac{\mathrm{R}_{\text {is }}}{\mathrm{\gamma Bh}_{\mathrm{i}}^{2}}=1.89+1.53 \mathrm{~F}_{\mathrm{n}}^{1.27}
$$

with a correlation coefficient $\mathrm{r}=0.987$. 
The resistance through level ice, in its dimensionless form, was then assumed to differ from eq 2 by only a power function of the dimensionless ice strength $\sigma / \gamma_{i}$. Nonlinear regression analysis of the data yielded

$$
\frac{\mathrm{R}_{\mathrm{i}}}{\gamma B \mathrm{~B}_{\mathrm{i}}{ }^{2}}=1.89+1.53 \mathrm{~F}_{\mathrm{n}}^{1.27}+8.2 \times 10^{-4}\left(\frac{\sigma}{\gamma \mathrm{h}}\right)^{1.7}
$$

with a correlation coefficient of 0.966 .

The dimensional form of eq 3 for the $1: 20$-scale mode1 is then

$$
\mathrm{R}_{i}=1.796 \mathrm{~h}_{\mathrm{i}}^{2}+6.328 \mathrm{v}^{1.27} \mathrm{~h}_{\mathrm{i}}^{1.37}+0.040 \mathrm{~h}_{\mathrm{i}}^{0.3} \sigma^{1.7}
$$

in which $\mathrm{R}_{i}$ is expressed in $\mathrm{N}$, $\mathrm{h}$ in $\mathrm{cm}, \mathrm{V}$ in $\mathrm{m} / \mathrm{s}$ and $\sigma$ in $\mathrm{kPa}$.

Other forms of the resistance equation

Several forms of the resistance in level ice have been proposed in the literature. The forms of these equations are usually based either on regression analysis of model tests or on physical consideration or on both. Among the equations proposed are those by Edwards (1980), eq 5a; Enkvist (1972), eq 5b; Poznyak and Ionov (1981), eq 5c; and Vance (1974), eq 5d,

$$
\begin{aligned}
& \mathrm{R}_{i}=a h_{i}^{2}+b h_{i} v^{2}+c h_{i} \sigma \\
& R_{i}=a h_{i}+b h_{i} v^{2}+c h_{i} \sigma \\
& R_{i}=a h_{i}+b v^{2}+c h_{i} \sigma \\
& R_{i}=a h_{i}^{2}+b h_{i}^{0.65} v^{2}+c h_{i} \sigma
\end{aligned}
$$

in which the coefficients $a, b$ and $c$ for a particular ship are to be determined from model tests. When the level ice resistance data obtained in the present model tests were analyzed according to the above formulas, the following values for the coefficients $a, b$ and $c$ and the corresponding correlation coefficients $r$ were obtained

\begin{tabular}{lrrrr} 
Formula & $\mathrm{a}$ & \multicolumn{1}{c}{$\mathrm{b}$} & $\mathrm{c}$ & $\mathrm{r}$ \\
\hline eq 5a & -0.082 & 10.08 & 0.404 & 0.976 \\
eq 5b & -0.791 & 8.78 & 0.440 & 0.977 \\
eq 5c & -0.125 & 19.46 & 0.434 & 0.971 \\
eq 5d & 0.238 & 11.93 & 0.403 & 0.975
\end{tabular}

for $\mathrm{R}_{i}$ in $\mathrm{N}, \mathrm{h}_{\mathbf{i}}$ in $\mathrm{cm}, \mathrm{V}$ in $\mathrm{m} / \mathrm{s}$ and $\sigma$ in $\mathrm{kPa}$. All of these various forms of the resistance equation lead to practically identical values of the correlation coefficient. However, except for Vance's form, they require a negative coefficient of the term in $h_{i}$ or $h_{i}{ }^{2}$, usually referred to as the submergence component of the ice resistance, which is unrealistic. 
Several empiric-analytical and purely analytical methods and equations for predicting ship resistance in level ice have been proposed. The earliest one is that by Kashtelyan et al. (1968) who expressed the ice resistance by

$$
\mathrm{R}_{i}=\mu_{\mathrm{o}}\left[0.004 \mathrm{~B} \mathrm{~h}_{\mathrm{i}} \sigma+3.6 \mathrm{~B} \gamma_{i} \mathrm{~h}_{i}{ }^{2}\right]+\frac{2450}{n_{2}} \mathrm{~B}^{1.65} \mathrm{~h}_{\mathrm{i}} \mathrm{V}
$$

where $R_{i}$ is expressed in $N, B$ and $h_{i}$ in $\mathrm{m}, \sigma$ in $P a$ and $V$ in $\mathrm{m} / \mathrm{s}$, and $\gamma_{i}$ is the specific weight of ice in $\mathrm{N} / \mathrm{m}^{3}$. The coefficients $H_{0}$ and $n_{2}$ are the socalled Shimansky coefficients, and are functions of the bow geometry. For the R-class icebreaker, $\mu_{0}=1.95$ and $n_{2}=1.50$. It should be noted that the numerical coefficients in eq 5 e were determined from model tests and fullscale measurements on the Soviet icebreaker Ermak, and are valid for a velocity range of 0 to $2.8 \mathrm{~m} / \mathrm{s}$ ( 5.5 knots), full-scale, and a maximum ice thickness of 1 to $1.2 \mathrm{~m}$.

Purely analytical methods have been presented by Milano (1973), Naegle (1980) and more recently by Carter (1983). Milano's and Naegle's methods require extensive and sophisticated computer programs not available at CRREL and so could not be tested against the present model test results. Carter's approach, through a series of assumptions and simplifications, led to a relatively simple equation, which in a consistent system of units reads

$$
\mathrm{R}_{i}=\sigma \mathrm{h}^{2}\left[1+0.4 \frac{\rho \mathrm{V}^{2}}{\sigma} \frac{\ell^{2}}{\mathrm{~h}_{i}^{2}}\right]^{1 / 2}\left(\mathrm{~A}_{1}+\mathrm{A}_{2}\right) \frac{\mathrm{B}}{\ell}
$$

where $\rho=$ density of water

$\ell=$ ice characteristic length,

$$
\ell=\left[\frac{E h_{i}^{3}}{12 \gamma\left(1-u^{2}\right)}\right]^{1 / 4}
$$

and $A_{1}$ and $A_{2}$ are parameters that characterize the ship hull

$$
\begin{aligned}
& A_{1}=0.5483\left(\frac{\pi}{2}-\theta\right) \frac{\sin \theta \sin \beta+f \cos \beta}{\sin \theta \cos \beta-f \sin \beta} \\
& A_{2}=0.75 \frac{1+2 \cos \beta}{(\sin \theta+\cos \theta)(1+2 \sin \delta)}\left\{\tan \beta+f\left(\frac{L_{b}}{B} \frac{2}{1+2 \cos \beta}+1.732 \tan \beta\right)\right\}
\end{aligned}
$$

where $\mathrm{L}_{\mathrm{b}} / 2 \equiv$ bow length from stem to maximum beam

$\beta \equiv$ stem angle with the horizontal

$\delta \equiv$ flare angle at maximum beam

$\theta \equiv$ bow opening angle. 


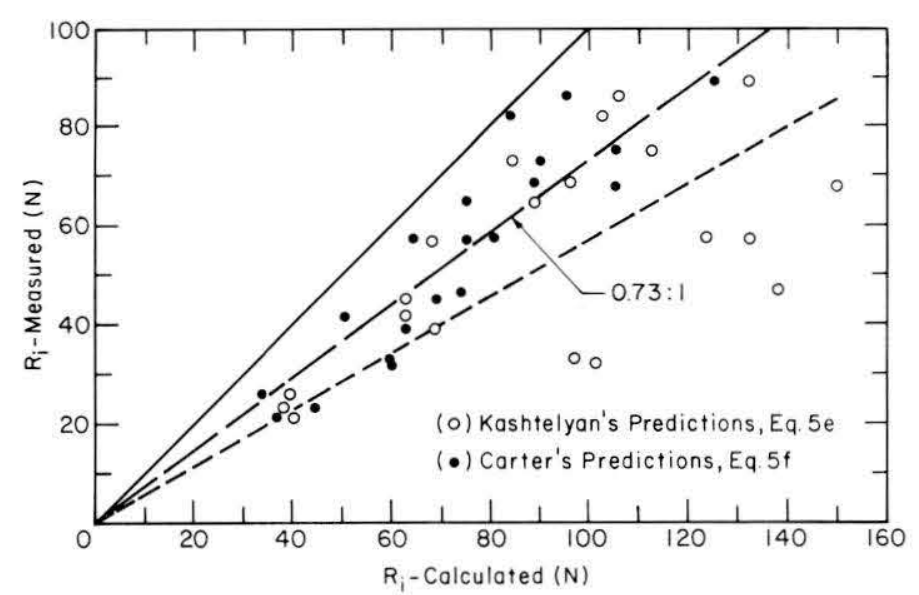

Figure 3. Comparison between ice resistance measurements and predictions by Kashtelyan's (Kashtelyan et a1. 1968) and Carter's (1983) equations.

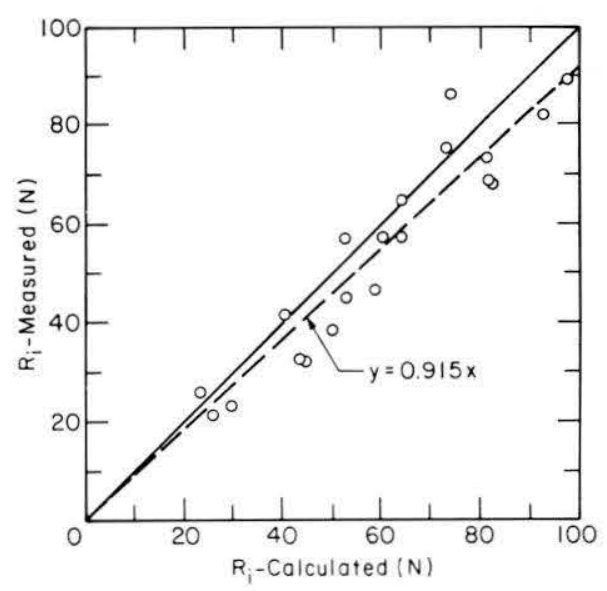

Figure 4. Comparison between ice resistance measurements and predictions by Carter's (1983) equation with $\mathrm{E} / \sigma=5000$.

The measured resistance of the R-class model is compared in Figure 3 against the resistance predicted by eq $5 \mathrm{e}$ and $5 \mathrm{f}$. All predictions are larger than the measured resistance, in particular those by Kashtelyan's equation (eq 5e) for the tests in thicker and weaker ice. It should be noted that the ice-hull friction coefficient does not appear explicitly in eq 5 e, but is implicitly contained in its empirical coefficents. It should also be noted that actual icebreakers usually have a higher friction factor (on the order of 0.15 to 0.25 ) than that of 0.04 measured with the tested mode1, which is likely to account for some of the difference between Kashtelyan's predictions and the measured values of the model ice resistance.

Linear regression analysis between Carter's prediction and test results yielded

$$
R_{i} \text { - measured }=0.73\left(R_{i}-\text { Carter }\right)
$$

with a correlation coefficient $r=0.945$. Carter's derivation of eq $5 \mathrm{f}$ suffers from serious weaknesses in the physical description of the ice-breaking phenomenon, and it would have been dismissed if comparison between predicted values and full-scale and model measurements of ice resistance for a number of ships had not shown extremely good agreement. However, in comparing his predictions with available data, Carter always assumed a ratio E/ $\sigma$ of 5000 . When applying eq $5 \mathrm{f}$ to the present test conditions, with the condition $\mathrm{E}=$ $5000 \sigma$, there was remarkable agreement between predictions and measurements as shown in Figure 4. Linear regression analysis of the data in Figure 4 yielded 


$$
R_{i}-\text { measured }=0.915\left(R_{i}-\text { Carter, } E / \sigma=5000\right)
$$

with a correlation factor $\mathrm{r}=0.945$.

\section{PROPULSION TESTS}

In the model propulsion tests, each propeller shaft is connected to a thrust and torque dynamometer. The input shafts of the dynamometer are driven by a $746 \mathrm{~W}$ (1-hp) variable speed motor through T-joints and a 1:1.7 gear reducer as shown in the photographs of Figure 1.

In these tests, the model remains connected to the towing post of the test basin carriage. The carriage speed $\mathrm{V}$ and propellers' rpm are set to preselected values, and the thrust and torque on the propellers are measured together with the pull exerted on the towing post.

Prior to the propulsion tests per se, bollard tests (i.e., tests at $\mathrm{V}=$ 0 for a range of propeller $\mathrm{rpm}$ ) were run for two reasons: to check the overall propulsion assembly by comparing the measured pull against that measured in the NRCC facilities (Murdey 1980), and to calibrate the dynamometers against the NRCC results since CRREL does not have the equipment necessary to perform in situ calibration of the dynamometers.

\section{Bollard tests}

The results of the forward bollard tests are listed in Table 6 . The pull is the actual force measured at the towpost force block, the thrust and torque listed are the sum of the thrust and torque for both propellers calibrated against the NRCC data. The pull measured in these bollard tests is compared to that obtained at NRCC (Murdey 1980) in Figure 5, which shows that the two sets of data are in perfect agreement.

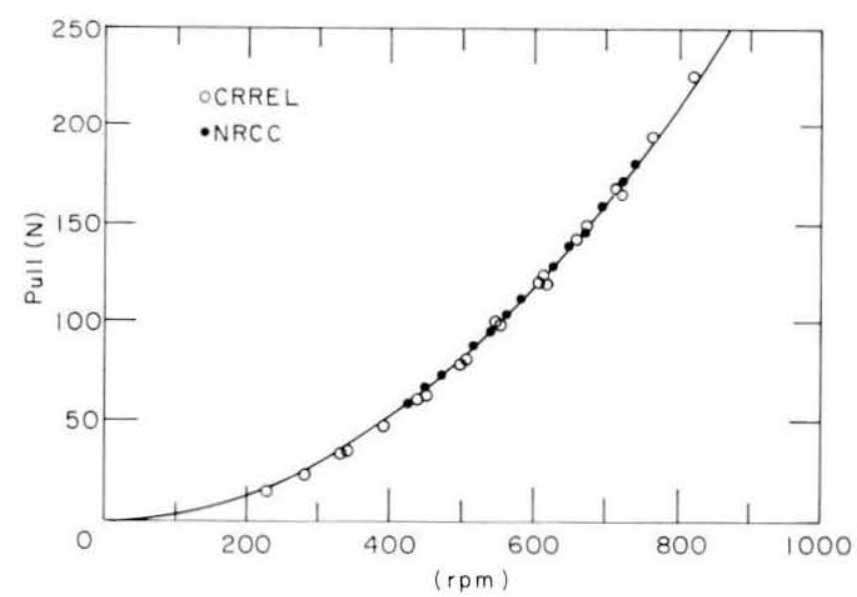

Figure 5. Comparison of pul1 force measured in forward bollard tests at CRREL and NRCC. 
Table 6. Results of forward bollard tests (thrust and torque are total measured values for both propellers).

\begin{tabular}{|c|c|c|c|}
\hline $\mathrm{Rpm}$ & $\begin{array}{l}\text { Pul1 } \\
(\mathrm{N})\end{array}$ & $\begin{array}{l}\text { Thrust } \\
\text { (N) }\end{array}$ & $\begin{array}{c}\text { Torque } \\
(\mathrm{Nm})\end{array}$ \\
\hline 224.00 & 14.37 & 15.97 & 0.40 \\
\hline 281.00 & 23.98 & 25.58 & 0.63 \\
\hline 282.00 & 23.35 & 24.95 & 0.61 \\
\hline 333.00 & 33.81 & 35.85 & 0.87 \\
\hline 336.00 & 34.83 & 35.67 & 0.91 \\
\hline 338.00 & 34.38 & 36.56 & 0.92 \\
\hline 338.00 & 35.41 & 35.85 & 0.92 \\
\hline 390.00 & 47.20 & 51.07 & 1.20 \\
\hline 390.00 & 46.71 & 50.80 & 1.24 \\
\hline 390.00 & 47.60 & 48.75 & 1.22 \\
\hline 442.00 & 61.39 & 64.37 & 1.57 \\
\hline 442.00 & 61.16 & 63.34 & 1.56 \\
\hline 448.00 & 63.03 & 65.97 & 1.64 \\
\hline 500.00 & 79.13 & 83.49 & 2.00 \\
\hline 501.00 & 79.71 & 84.52 & 2.03 \\
\hline 503.00 & 80.51 & 84.87 & 2.04 \\
\hline 550.00 & 97.15 & 103.02 & 2.45 \\
\hline 551.00 & 98.17 & 101.55 & 2.48 \\
\hline 553.00 & 96.75 & 102.31 & 2.50 \\
\hline 553.00 & 98.80 & 101.42 & 2.49 \\
\hline 608.00 & 120.10 & 123.57 & 3.02 \\
\hline 610.00 & 120.90 & 125.75 & 3.05 \\
\hline 612.00 & 119.17 & 124.73 & 3.12 \\
\hline 612.00 & 122.28 & 126.11 & 3.07 \\
\hline 659.00 & 142.08 & 143.81 & 3.56 \\
\hline 661.00 & 141.81 & 148.93 & 3.72 \\
\hline 671.00 & 148.39 & 152.57 & 3.72 \\
\hline 714.00 & 167.74 & 169.48 & 4.19 \\
\hline 720.00 & 164.72 & 173.75 & 4.35 \\
\hline 765.00 & 193.19 & 195.99 & 4.81 \\
\hline 822.00 & 225.12 & 233.58 & 5.60 \\
\hline 425.00 & 58.91 & 61.15 & 1.51 \\
\hline 447.00 & 65.40 & 68.00 & 1.68 \\
\hline 470.00 & 72.20 & 75.20 & 1.85 \\
\hline 514.00 & 86.90 & 90.60 & 2.22 \\
\hline 537.00 & 94.70 & 98.80 & 2.42 \\
\hline 559.00 & 102.60 & 107.20 & 2.63 \\
\hline 581.00 & 111.00 & 116.20 & 2.84 \\
\hline 626.00 & 128.80 & 135.00 & 3.29 \\
\hline 648.00 & 138.30 & 145.00 & 3.53 \\
\hline 671.00 & 148.10 & 155.30 & 3.78 \\
\hline 693.00 & 158.40 & 166.00 & 4.04 \\
\hline 716.00 & 169.40 & 177.00 & 4.30 \\
\hline 738.00 & 180.70 & 188.40 & 4.57 \\
\hline
\end{tabular}


Twenty-four tests were run to cover the range of velocity, ice thickness and ice strength required in the test program of the ITTC committee. The test conditions and tests results are listed in Table 7.

To check the proper functioning of the thrust and torque dynamometers and, if necessary, to adjust or correct the thrust and torque measurements, forward bollard tests in ice-free water were conducted immediately before and after each propulsion test.

From the results obtained for each pair of tests run at nominally identical velocity, ice thickness and ice strength, but at two different propeller speeds, the propellers' rpm at which the pull would be zero (self-propulsion point) was interpolated as well as the corresponding propeller thrust and torque. The corresponding total resistance of the model in ice-covered water was calculated as $R_{i t}=R_{i}+R_{\text {ow }}$ with $R_{i}$ given by eq 2 and $R_{\text {ow }}$ by eq 1 . The results are given in Table 8 . In both Tables 7 and 8 , the thrust $\mathrm{T}_{\mathrm{A}}$ and torque $Q_{A}$ are the total values for both propellers.

Table 7. Results of propulsion tests in level ice (thrust and torque are total measured values for both propellers).

\begin{tabular}{lllllrrr}
$\begin{array}{c}\mathrm{V} \\
(\mathrm{m} / \mathrm{s})\end{array}$ & $\begin{array}{c}\mathrm{h}_{\mathrm{i}} \\
(\mathrm{cm})\end{array}$ & $\begin{array}{c}\sigma \\
(\mathrm{kPa})\end{array}$ & $\begin{array}{c}\mathrm{E} \\
(\mathrm{MPa})\end{array}$ & $\begin{array}{c}\mathrm{n}_{\mathrm{A}} \\
(\mathrm{rpm})\end{array}$ & \multicolumn{1}{c}{$\begin{array}{r}\mathrm{Pu} 11 \\
(\mathrm{~N})\end{array}$} & \multicolumn{1}{c}{$\begin{array}{c}\mathrm{T}_{\mathrm{A}} \\
(\mathrm{N})\end{array}$} & $\begin{array}{l}\mathrm{Q}_{\mathrm{A}} \\
(\mathrm{Nm})\end{array}$ \\
\hline 0.11 & 2.74 & 37.00 & 48.00 & 236.00 & -18.00 & 23.60 & 0.40 \\
0.11 & 2.71 & 30.00 & 48.00 & 334.00 & 8.80 & 40.70 & 0.88 \\
0.56 & 2.61 & 43.00 & 48.00 & 358.00 & -36.60 & 30.30 & 0.92 \\
0.56 & 2.66 & 40.00 & 48.00 & 490.00 & -0.90 & 77.90 & 1.69 \\
1.19 & 2.68 & 50.00 & 48.00 & 510.00 & -84.40 & 72.80 & 1.95 \\
1.27 & 2.79 & 45.00 & 48.00 & 694.00 & -14.30 & 121.00 & 3.10 \\
0.11 & 2.69 & 26.00 & 13.00 & 222.00 & -17.50 & 15.20 & 0.35 \\
0.11 & 2.75 & 22.00 & 13.00 & 332.00 & 11.10 & 31.10 & 0.83 \\
0.55 & 2.80 & 27.00 & 13.00 & 332.00 & -35.10 & 40.10 & 0.73 \\
0.52 & 2.90 & 25.00 & 13.00 & 497.00 & 9.70 & 71.90 & 1.90 \\
1.26 & 2.80 & 28.00 & 13.00 & 443.00 & -100.90 & 38.50 & 1.04 \\
1.26 & 2.85 & 28.00 & 13.00 & 670.00 & -29.40 & 111.10 & 2.84 \\
0.11 & 3.70 & 24.00 & 12.00 & 269.00 & -21.20 & 20.40 & 0.54 \\
0.11 & 3.70 & 18.00 & 12.00 & 368.00 & 8.20 & 41.80 & 1.03 \\
0.33 & 3.65 & 25.00 & 12.00 & 377.00 & -48.20 & 39.10 & 1.14 \\
0.29 & 3.70 & 25.00 & 12.00 & 520.00 & 14.80 & 80.10 & 2.02 \\
0.53 & 3.85 & 30.00 & 12.00 & 399.00 & -54.00 & 40.70 & 1.34 \\
0.58 & 3.90 & 30.00 & 12.00 & 608.00 & 25.80 & 111.10 & 2.66 \\
0.11 & 3.20 & 38.00 & 41.00 & 337.00 & -12.30 & 35.90 & 0.87 \\
0.11 & 3.30 & 35.00 & 41.00 & 502.00 & 41.90 & 80.10 & 1.99 \\
0.34 & 3.40 & 43.00 & 41.00 & 393.00 & -32.90 & 47.90 & 1.33 \\
0.34 & 3.47 & 41.00 & 41.00 & 612.00 & 41.80 & 115.00 & 2.97 \\
0.55 & 3.52 & 44.00 & 41.00 & 446.00 & -53.70 & 54.30 & 2.12 \\
0.55 & 3.70 & 44.00 & 41.00 & 720.00 & 48.80 & 162.90 & 4.12 \\
\hline
\end{tabular}


Table 8. Calculated self-propulsion points of model.

\begin{tabular}{lccccccccc}
$\begin{array}{c}\mathrm{V} \\
(\mathrm{m} / \mathrm{s})\end{array}$ & $\begin{array}{c}\mathrm{h}_{\mathrm{i}} \\
(\mathrm{cm})\end{array}$ & $\begin{array}{c}\sigma \\
(\mathrm{kPa})\end{array}$ & $\begin{array}{c}\mathrm{R}_{\mathrm{it}} \\
(\mathrm{N})\end{array}$ & $\begin{array}{c}\mathrm{n}_{\mathrm{A}} \\
(\mathrm{rpm})\end{array}$ & $\begin{array}{c}\mathrm{T}_{\mathrm{A}} \\
(\mathrm{N})\end{array}$ & $\begin{array}{c}\mathrm{Q}_{\mathrm{A}} \\
(\mathrm{Nm})\end{array}$ & $\mathrm{J}_{\mathrm{v}}$ & $\mathrm{K}_{\mathrm{T}}$ & $10 \mathrm{~K}_{\mathrm{Q}}$ \\
\hline 0.11 & 2.73 & 33.5 & 36 & 305 & 36 & 0.70 & 0.105 & 0.384 & 0.363 \\
0.11 & 2.73 & 24.0 & 27 & 293 & 25 & 0.65 & 0.109 & 0.291 & 0.367 \\
0.11 & 3.70 & 22.0 & 37 & 348 & 37 & 0.93 & 0.092 & 0.305 & 0.373 \\
0.11 & 3.25 & 36.5 & 47 & 394 & 46 & 1.20 & 0.081 & 0.296 & 0.375 \\
0.31 & 3.67 & 25.0 & 49 & 488 & 71 & 1.70 & 0.185 & 0.298 & 0.346 \\
0.34 & 3.43 & 42.0 & 65 & 498 & 77 & 2.07 & 0.199 & 0.310 & 0.405 \\
0.56 & 2.63 & 41.5 & 60 & 491 & 79 & 1.70 & 0.332 & 0.328 & 0.342 \\
0.54 & 2.85 & 26.5 & 47 & 466 & 62 & 1.62 & 0.338 & 0.285 & 0.362 \\
0.55 & 3.87 & 30.0 & 71 & 545 & 84 & 2.25 & 0.294 & 0.283 & 0.368 \\
0.55 & 3.61 & 44.0 & 83 & 609 & 112 & 3.20 & 0.263 & 0.302 & 0.419 \\
1.23 & 2.73 & 47.5 & 114 & 728 & 130 & 3.35 & 0.492 & 0.245 & 0.307 \\
1.26 & 2.82 & 28.0 & 94 & 740 & 140 & 3.45 & 0.496 & 0.256 & 0.306 \\
\hline
\end{tabular}

The thrust coefficient $\mathrm{K}_{\mathrm{T}}=\mathrm{T}_{\mathrm{A}} / 2 \rho \mathrm{n}_{\mathrm{A}}{ }^{2} \mathrm{D}^{4}$ and torque coefficient $\mathrm{K}_{\mathrm{Q}}=$ $\mathrm{Q}_{\mathrm{A}} / 2 \rho \mathrm{n}_{\mathrm{A}}{ }^{2} \mathrm{D}^{5}$ in Tables 7 and 8 have been plotted versus the apparent advance coefficient $\mathrm{J}_{\mathrm{v}}=\mathrm{V} / \mathrm{n}_{\mathrm{A}} \mathrm{D}$ in Figure 6 . In spite of the scatter in the data, to be expected because of intermittent ice-propeller interaction, the following equations could be fitted through the experimental results

$$
\begin{aligned}
\mathrm{K}_{\mathrm{T}} & =0.308-0.011 \mathrm{~J}_{\mathrm{v}}-0.167 \mathrm{~J}_{\mathrm{v}}{ }^{2} \\
10 \mathrm{~K}_{\mathrm{Q}} & =0.371+0.046 \mathrm{~J}_{\mathrm{v}}-0.248 \mathrm{~J}_{\mathrm{V}}{ }^{2} .
\end{aligned}
$$

In Figure 7 , the estimated total thrust delivered by the propellers has been plotted against the calculated total resistance in level ice at the self-propulsion points of the ship model. These values satisfy the linear regression

$$
\mathrm{T}_{\mathrm{A}}=1.25 \mathrm{R}_{\mathrm{it}}
$$

with a correlation $\mathrm{r}=0.96$. From eq $8 \mathrm{a}$, the thrust deduction factor, $\mathrm{t}=$ $1-\mathrm{R}_{\mathrm{it}} / \mathrm{T}_{\mathrm{A}}$, in level ice was calculated as

$$
t=0.2 \text {. }
$$

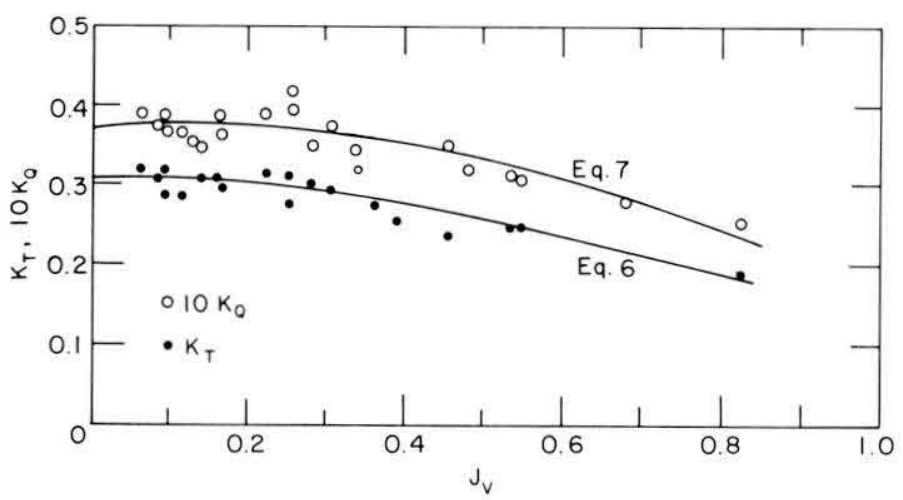

Figure 6. Thrust and torque coefficients in level ice versus apparent advance coefficient. 


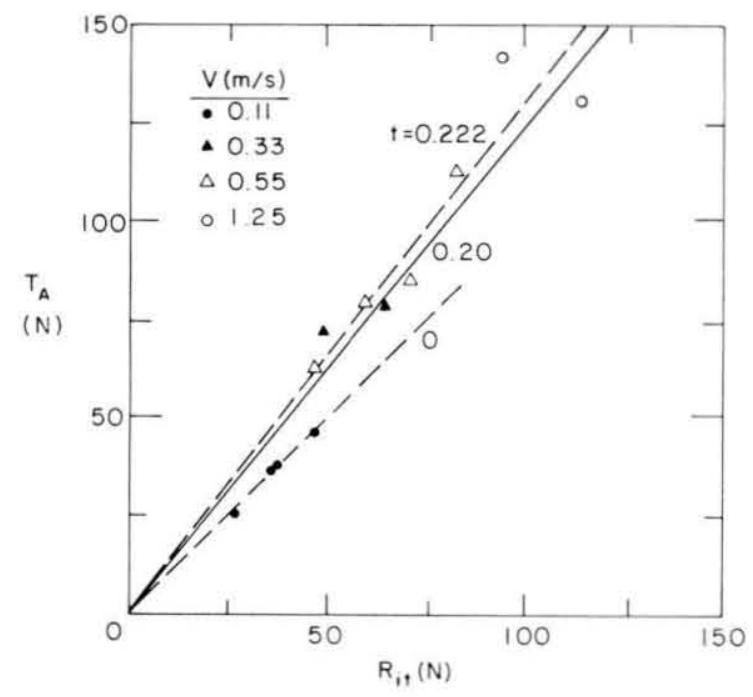

Figure 7. Mode1 total thrust versus model total resistance in level ice at self-propulsion points.

The data points for the velocity of $0.11 \mathrm{~m} / \mathrm{s}$ lie on the line $\mathrm{T}_{\mathrm{A}}=\mathrm{R}_{\mathrm{it}}$, indicating a thrust deduction factor of zero. It is more likely that the fluctuations in thrust and resistance measurements always present during ice tests did not permit determination of low values on $t$, on the order of 0.05 or less, such as were obtained in the low velocity tests in ice free conditions (Murdey 1980). The data obtained at velocities greater than $0.11 \mathrm{~m} / \mathrm{s}$ yield

$$
\mathrm{T}_{\mathrm{A}}=1.285 \mathrm{R}_{\mathrm{it}}
$$

which corresponds to

$$
\mathrm{t}=0.222 \text {. }
$$

\section{FULL-SCALE PERFORMANCE PREDICTIONS}

Based on the above analysis of the model test data, full-scale performance of the CCGS R-class icebreaker is predicted as follows:

1. Under the Froude scaling law, the full-scale ice resistance is equal to $\lambda^{3}$ times the model resistance where $\lambda$ is the geometric scale, equal to 20 in the present case. From the model resistance equation, eq 3 , the fullscale ice resistance is given by

$$
\mathrm{R}_{\mathbf{i}}=359 \mathrm{~h}_{\mathbf{i}}^{2}+68.4 \mathrm{v}^{1.27} \mathrm{~h}_{\mathbf{i}}{ }^{1.37}+3.21 \times 10^{-3} \mathrm{~h}_{\mathbf{i}} 0.3 \sigma^{1.7}
$$

where $R_{i}$ is expressed in $\mathrm{kN}, \mathrm{h}_{i}$ in $\mathrm{m}, \mathrm{V}$ in $\mathrm{m} / \mathrm{s}$ and $\sigma$ in $\mathrm{kPa}$.

The total resistance is given by

$$
R_{i t}=R_{i}+R_{\text {ow }}
$$

in which $\mathrm{R}_{\mathrm{OW}}$ is obtained from the results of Murdey (1980). 


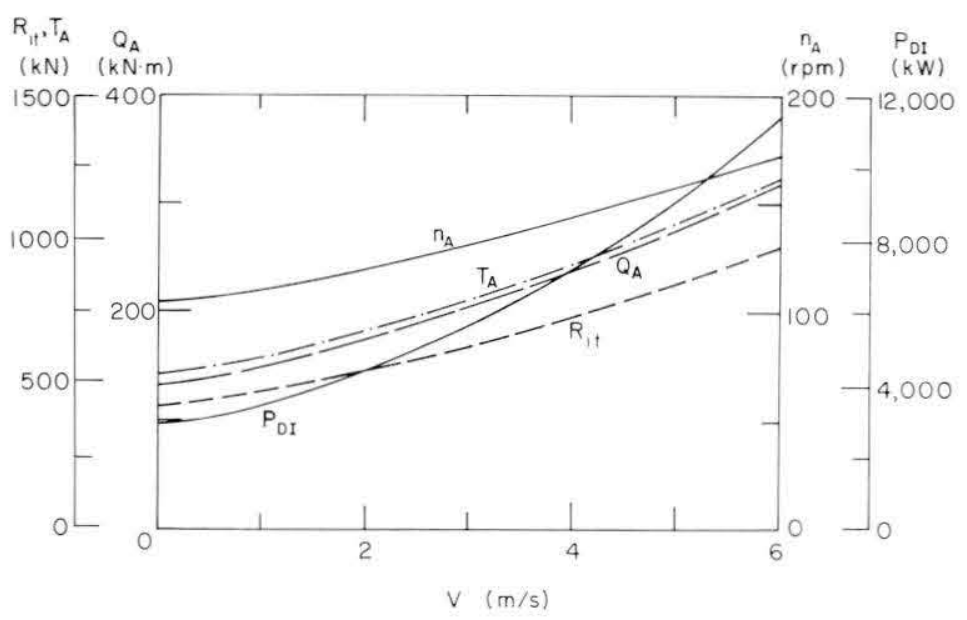

a. $\mathrm{h}_{i}=0.7 \mathrm{~m}, \sigma=800 \mathrm{kPa}$.

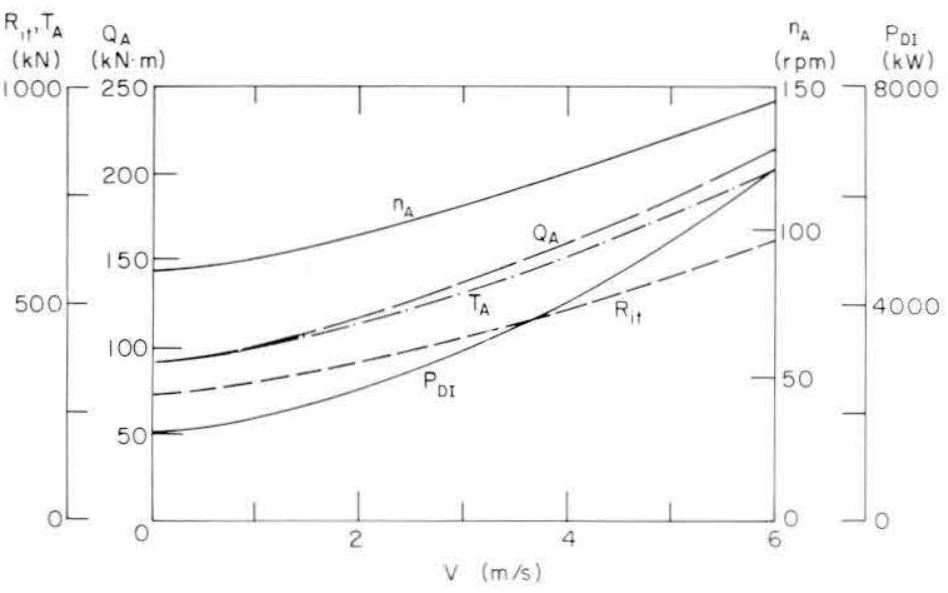

b. $\mathrm{h}_{i}=0.45 \mathrm{~m}, \sigma=800 \mathrm{kPa}$.

Figure 8. Predicted full-scale performance.

2. A constant thrust deduction coefficient $t=0.2$ is selected that is likely to be conservative at low velocity

$$
\mathrm{T}_{\mathrm{A}}=1.25 \mathrm{R}_{\text {it }} \text {. }
$$

3. The required propeller speed, $n_{A}$, in $r p m$ is next calculated from eq 6 , and the corresponding total torque from eq 7 . The resulting delivered power is calculated by

$$
\mathrm{P}_{\mathrm{DI}}=2 \pi\left(\frac{\mathrm{n}_{\mathrm{A}}}{60}\right) \mathrm{Q}_{\mathrm{A}} \text {. }
$$

Calculations have been made for four conditions, namely: 1) $h_{i}=0.70 \mathrm{~m}$, $\sigma=800 \mathrm{kPa} ; 2) \mathrm{h}_{i}=0.45 \mathrm{~m}, \sigma=800 \mathrm{kPa}$; 3) $\mathrm{h}_{i}=0.70 \mathrm{~m}, \sigma=400 \mathrm{kPa}$, and 4) $\mathrm{h}=0.45 \mathrm{~m}, \sigma=400 \mathrm{kPa}$. The results are presented in Figure 8 and in Appendix A. 


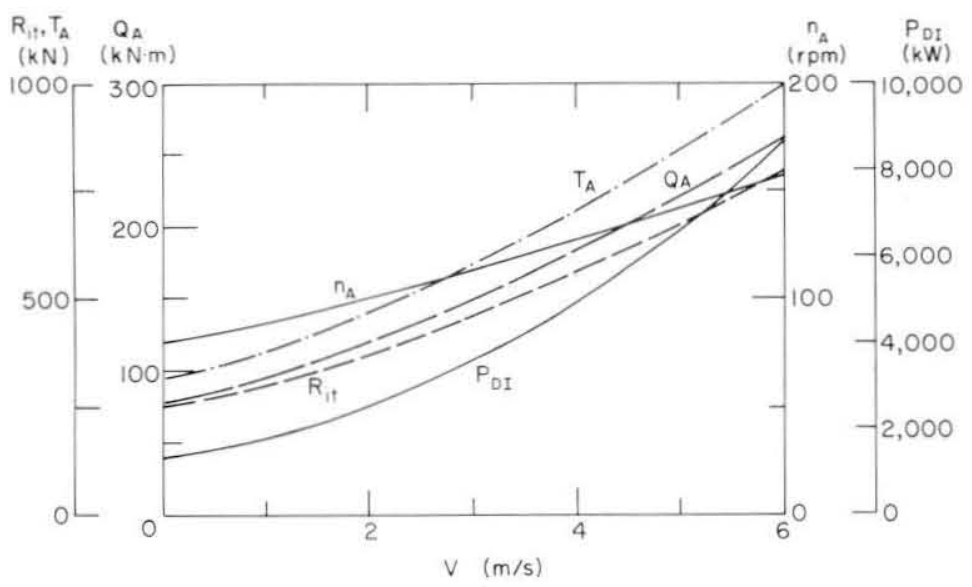

c. $\mathrm{h}_{\mathrm{i}}=0.7 \mathrm{~m}, \sigma=400 \mathrm{kPa}$.

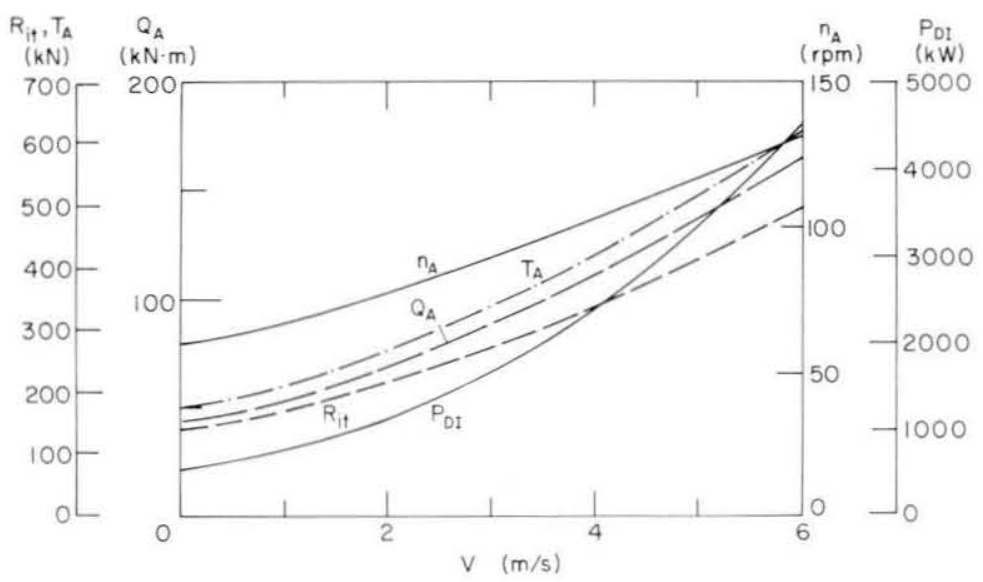

d. $\mathrm{h}_{\mathrm{i}}=0.45 \mathrm{~m}, \sigma=400 \mathrm{kPa}$.

Figure 8 (cont'd).

COMPARISON WITH FULL-SCALE TRIAL DATA

A relatively complete set of full-scale measurements have been presented by Michailidis and Murdey (1981). The range of parameters $\mathrm{V}, \mathrm{h}_{i}$ and $\sigma$ of the full-scale trials were within that of the present model tests or nearly so. The primary difference was the presence of a snow cover that was not modeled in the laboratory tests. The presence of snow adds another component to the total resistance, namely the snow resistance $R_{S}$. Little is known about this resistance component. In a recent report, Carter (1983) assumed that $R_{S}$ is proportional to the snow cover thickness $h_{S}$

$$
\mathrm{R}_{\mathrm{S}}=\mathrm{k} \mathrm{h}_{\mathrm{S}}
$$

and suggested the value $k=900$ when $R_{S}$ is expressed in $k N$ and $h_{S}$, the snow cover thickness, in m. For lack of better predictor, eq 14 with $\mathrm{k}=900$ was 
Table 9. Calculated versus measured full-scale performance (field measurement from Michailidis and Murdey 1981).

Field

\begin{tabular}{|c|c|c|c|c|c|c|c|c|c|c|c|}
\hline \multirow[b]{2}{*}{$\begin{array}{c}V \\
(\mathrm{~m} / \mathrm{s}) \\
\end{array}$} & \multirow[b]{2}{*}{$\begin{array}{c}\mathrm{h}_{\mathrm{i}} \\
(\mathrm{cm})\end{array}$} & \multirow[b]{2}{*}{$\begin{array}{c}\sigma \\
(\mathrm{kPa}) \\
\end{array}$} & \multirow[b]{2}{*}{$\begin{array}{l}\mathrm{h}_{\mathrm{s}} \\
(\mathrm{cm})\end{array}$} & \multicolumn{5}{|c|}{ Calculated values } & \multicolumn{3}{|c|}{ measurements } \\
\hline & & & & $\begin{array}{l}\mathrm{R}_{\mathrm{it}} \\
(\mathrm{kN}) \\
\end{array}$ & $\begin{array}{c}\mathrm{R}_{\mathrm{S}} \\
(\mathrm{kN})\end{array}$ & $\begin{array}{c}\mathrm{n}_{\mathrm{A}} \\
(\mathrm{rpm})\end{array}$ & $\begin{array}{r}\mathrm{T}_{\mathrm{A}^{*}} \\
(\mathrm{kN})\end{array}$ & $\begin{array}{l}\mathrm{P}_{\mathrm{DI}^{* *}} \\
(\mathrm{~kW})\end{array}$ & $\begin{array}{l}\mathrm{n}_{\mathrm{A}} \\
(\mathrm{rpm})\end{array}$ & $\begin{array}{r}\mathrm{T}_{\mathrm{A}^{*}} \\
(\mathrm{kN})\end{array}$ & $\begin{array}{l}\mathrm{PDI}^{* *} \\
(\mathrm{~kW})\end{array}$ \\
\hline 1.12 & 70.4 & 510 & 8.0 & 349 & 72 & 104 & 526 & 2913 & 119 & 578 & 3860 \\
\hline 2.38 & 62.0 & 480 & 13.0 & 370 & 117 & 115 & 609 & 3773 & 127 & 648 & 4510 \\
\hline 2.77 & 67.4 & 460 & 9.0 & 436 & 81 & 119 & 647 & 4172 & 133 & 707 & 5510 \\
\hline 2.08 & 67.6 & 460 & 15.0 & 381 & 135 & 117 & 645 & 4057 & 145 & 826 & 7450 \\
\hline 3.63 & 65.0 & 460 & 11.0 & 495 & 99 & 130 & 742 & 5250 & 155 & 917 & 8020 \\
\hline 4.23 & 66.6 & 460 & 12.0 & 571 & 108 & 140 & 848 & 6489 & 172 & 1056 & 10900 \\
\hline 3.93 & 61.3 & 460 & 9.0 & 489 & 81 & 128 & 712 & 5002 & 164 & 957 & 9190 \\
\hline 1.82 & 73.8 & 300 & 52.0 & 355 & 468 & 146 & 1028 & 8012 & 164 & 1177 & 10950 \\
\hline 0.99 & 75.4 & 300 & 48.0 & 303 & 432 & 137 & 919 & 6651 & 154 & 1094 & 9540 \\
\hline 0.80 & 88.3 & 300 & 50.0 & 377 & 450 & 145 & 1033 & 7894 & 144 & 980 & 7900 \\
\hline
\end{tabular}

*Total thrust.

**Total delivered power.

adopted here in the calculation of the predicted total resistance of the CCGS $\mathrm{R}$-class icebreaker for the full-scale trial conditions of velocity, ice thickness and strength, and snow cover thickness. The total resistance in snow covered ice is thus given by

$$
\mathrm{R}_{\mathrm{T}}=\mathrm{R}_{\mathrm{i}}+\mathrm{R}_{\mathrm{OW}}+\mathrm{k} \mathrm{h}_{\mathrm{S}} \text {. }
$$

The corresponding rpm, thrust and delivered power were calculated following steps 2 and 3 of the preceding section. The results of the calculations are listed in Table 9 together with the measured values from Michailidis and Murdey (1981), and are compared against the latter in Figure 9. As can be seen, the calculated values for the propeller speed, thrust and delivered power are consistently lower than the measured ones by an average of $13.1,14.4$ and $28.8 \%$ respectively.

An indirect check of the validity of the model test results can be made by calculating the thrust and power delivered by the propellers for the full-

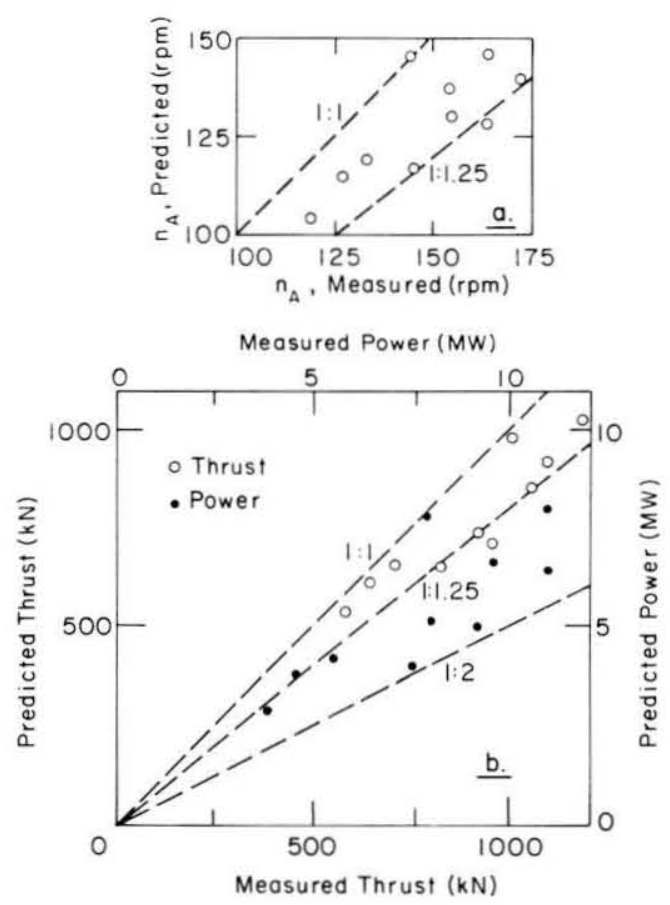

Figure 9. Predicted versus measured full-scale performance ( $a$ - propeller speed, b - total thrust and power). 
Table 10. Calculated and measured thrust and power at full-scale speed and propeller rpm.

\begin{tabular}{lcccrr}
$\begin{array}{c}\mathrm{V} \\
(\mathrm{m} / \mathrm{s})\end{array}$ & $\begin{array}{c}\mathrm{n}_{\mathrm{A}} \\
(\mathrm{rpm})\end{array}$ & $\begin{array}{c}\text { Measured } \\
\text { thrust } \\
(\mathrm{kN})\end{array}$ & $\begin{array}{c}\text { Cal culated } \\
\text { thrust } \\
(\mathrm{kN})\end{array}$ & $\begin{array}{c}\text { Measured } \\
\text { power } \\
(\mathrm{MW})\end{array}$ & $\begin{array}{c}\text { Cal culated } \\
\text { power } \\
(\mathrm{MW})\end{array}$ \\
\hline & & & & & \\
1.12 & 119.0 & 578 & 688 & 3.86 & 4.34 \\
2.39 & 126.7 & 648 & 751 & 4.51 & 5.12 \\
2.77 & 133.3 & 707 & 823 & 5.51 & 5.92 \\
2.08 & 144.5 & 827 & 997 & 7.45 & 7.70 \\
3.63 & 155.2 & 917 & 1098 & 8.02 & 9.24 \\
4.23 & 172.0 & 1056 & 1339 & 10.09 & 12.51 \\
3.93 & 163.5 & 957 & 1214 & 9.19 & 10.77 \\
1.82 & 163.8 & 1177 & 1296 & 10.95 & 11.29 \\
0.99 & 153.5 & 1094 & 1152 & 9.54 & 9.32 \\
0.80 & 143.6 & 980 & 1009 & 7.90 & 7.62 \\
\hline
\end{tabular}

scale values of ship velocity and prope1ler rpm and comparing the results with the measured full-scale values. The results of these calculations are presented in Table 10 and Figure 10. The calculated thrust and power are now somewhat higher than the measured values by an average of $13.7 \%$ for the thrust and only $7.7 \%$ for the power. These latter results, especially the very good agreement between measured and calculated power, indicate that the propeller characteristics represented by the relationships between advance coefficient $J$ and thrust and torque coefficients, $\mathrm{K}_{\mathrm{T}}$ and $\mathrm{K}_{\mathrm{Q}}$ (eq 6 and 7 respectively), were sat-

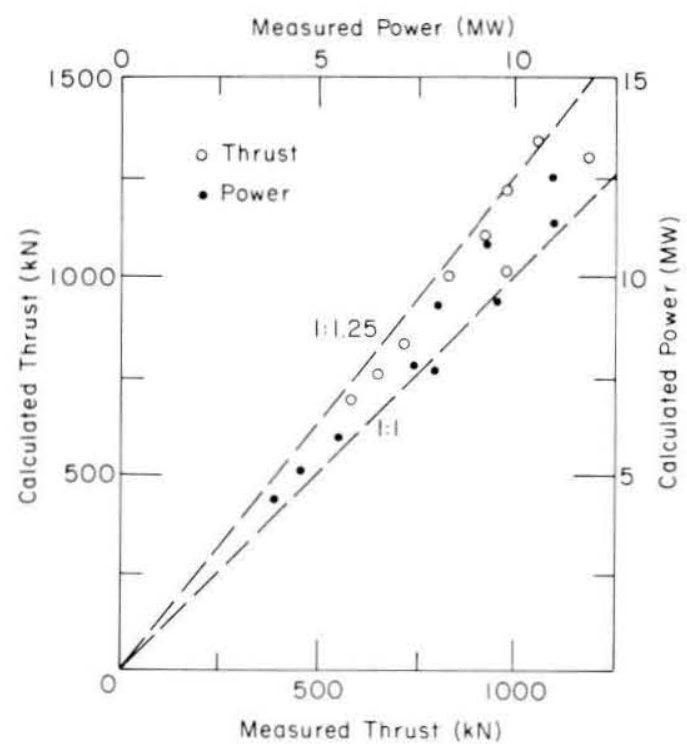

Figure 10. Calculated versus measured thrust and power at full-scale speed and propeller rpm. isfactorily duplicated in the model tests.

The sizable discrepancy between the measured thrust, rpm and, especial$1 y$, delivered power and their calculated values based on the ice resistance predicted by eq 15,14 and 10 may be attributed to several factors: 1) eq 10 predicts too low an ice resistance $R_{i}, 2$ ) the thrust deduction coefficient value of $t=0.2$ deduced from the model test results is incorrect, 3 ) the assumed coefficient $k=900$ in eq 14 for the calculation of $R_{S}$ is incorrect, and 4) a combination of the three above factors. 
Let us assume for the time being that the ice resistance given by eq 10 is indeed correct, and that the main sources of disagreement are erroneous values of $k$ and $t$. A regression analysis of the measured values of $T_{A}$ versus the calculated $R_{i t}$ and measured snow thickness according to the equation

$$
\mathrm{T}_{\mathrm{A}}=\frac{\mathrm{R}_{\mathrm{it}}+\mathrm{k} \mathrm{h}_{\mathrm{s}}}{1-\mathrm{t}}
$$

yielded values of

$$
\begin{aligned}
\mathrm{k} & =661 \mathrm{kN} / \mathrm{m} \\
\mathrm{t} & =0.37
\end{aligned}
$$

with a correlation factor of 0.914 . While the value of $k$ may be valid, a thrust deduction coefficient of 0.37 is unrealistically high. This writer is of the opinion that the discrepancy between the measured and calculated values of thrust, rpm and particularly power arises primarily from an underestimation of the ice resistance $R_{i}$ by eq 10 . This underestimation of $R_{i}$ is likely from too low a friction factor of the model as compared to that of the full-scale ship. As stated earlier, the model friction coefficent was measured at 0.04 . That of the ship was not measured during the trials reported by Michailidis and Murdey (1981), but Edwards et al. (1981), who describe full-scale trials of a sister ship, reported that the ice-hull friction coefficient was equal to 0.30 at 1 ow speed and 0.19 at high speed. Additional model tests at an ice-hull friction factor $f$ of the order of 0.2 would be needed to determine the effect of $f$ on the coefficients of eq 10 and to verify the above contention. Because the full-scale trials reported by Edwards et al. (1981) were conducted at a lower draft of $6.08 \mathrm{~m}$-- with corresponding changes in beam and length at waterline, wetted surface area and displacement -- than the present model tests, comparison of these trials' results with the predictions from the model tests would be invalid.

SUMMARY AND CONCLUSIONS

1. Resistance and propulsion tests were made on a 1:20-scale model of the latest Canadian Coast Guard R-class icebreaker. Resistance tests were made in level ice and in precut ice, and a resistance equation was derived. Propulsion tests were made in level ice only. These tests gave an average value of 0.20 for the thrust deduction factor. Relationships between the thrust and torque coefficients, $\mathrm{K}_{\mathrm{T}}$ and $\mathrm{K}_{\mathrm{Q}}$, and the apparent advance coefficient $\mathrm{J}_{\mathrm{V}}$ were established. 
2. From the model tests, an equation for the full-scale resistance in level ice was established, and self-propulsion characteristics for the four sets of ice conditions prescribed by the ITTC committee were calculated.

3. Comparison between predicted ship performance and available fullscale trial measurements was attempted. This required an assumption of the additional resistance from the snow cover on the ice.

The predicted propeller rpm, thrust and especially delivered power based on the resistance equation derived from the test results were significantly lower than the corresponding measured values. On the other hand, the predicted thrust and power calculated for the measured full-scale values of ship speed and propeller rpm were somewhat higher but in much better agreement with those measured during the field trials.

It was concluded that the ice resistance was underestimated in the mode 1 tests as compared to that of the full-scale ship primarily because the model had a much lower ice-hull friction coefficient. It would therefore be desirable to repeat the model tests with a higher model friction coefficient on the order of 0.2 as compared to its value of 0.04 in the present tests.

\section{LITERATURE CITED}

Carter, D. (1983) Ship resistance to continuous motion in level ice. Montreal: Transport Canada Report No. TP-3679E.

Committee on Ships in Ice-Covered Waters (1981) Report of Committee on Ships in Ice-Covered Waters. Proceedings, 16th Internationa1 Towing Tank Conference, Leningrad, U.S.S.R., vol. 1, pp. 363-376.

Edwards, R.Y., Jr. (1980) Modeling the interaction between ice and ships. In Physics and Mechanics of Ice, IUTAM Conference, Copenhagen 1979 (P. Tryde, Ed.). Berlin: Springer-Verlag, pp. 60-81.

Edwards, R.Y., M.A. Dunne, G. Comfort, V. Bulat and B. Johnson (1981) Results of full-scale trials in ice of CCGS Pierre Radison. Proceedings, Sixth Ship Technology and Research (STAR) Symposium, June. Ottawa: Society of Naval Architects and Marine Engineers, pp. 291-310.

Enkvist, E. (1972) On the ice resistance encountered by ships in the continuous mode of icebreaking. Helsinki: Swedish Academy of Engineering Sciences in Finland, Report No. 24.

Kashtelyan, V.I., I.I. Poznyak and A.J. Ryvlin (1968) Ice Resistance to Motion of a Ship. Leningrad: Sudostroenie.

Michailidis, M. and D.C. Murdey (1981) Performance of CCGS Frank1in in Lake Melville, 1980. Proceedings, Sixth Ship Technology and Research (STAR) 
Symposium, June. Ottawa, Canada: Society of Naval Architects and Marine Engineers, pp. 311-322.

Milano, R.V. (1973) Ship resistance to continuous motion in ice. Transactions, Society of Naval Architects and Marine Engineers, vol. 81, pp. 274-306.

Murdey, D.C. (1980) Resistance and propulsion experiments with mode1 327-1 and propellers 66L and 66R. Ottawa, Canada: Division of Mechanical Engineering, National Research Council, Technical Report No. LTR-SH-269.

Naegle, J.N. (1980) Ice-resistance prediction and motion simulation for ships operating in the continuous mode of icebreaking. Ph.D. dissertation. University of Michigan, Ann Arbor.

Noble, P. and V. Bulat (1979) Final report on optimization of bow forms for a medium icebreaker. Arctec Canada Report No. $461 \mathrm{C}$.

Poznyak, I.I. and B.P. Ionov (1981) The division of icebreaker resistance into components. Proceedings, Sixth Ship Technology Research (STAR) Symposium, June. Ottawa, Canada: Society of Naval Architects and Marine Engineers, pp. 249-252.

Vance, G.P. (1974) A modeling system for vessels in ice. Ph.D. dissertation. University of Rhode Island. 
APPENDIX A: PREDICTED FULL-SCALE PERFORMANCE.

\begin{tabular}{cccccc}
$\begin{array}{c}\mathrm{V} \\
(\mathrm{m} / \mathrm{s})\end{array}$ & $\begin{array}{c}\mathrm{R}_{\mathrm{it}} \\
(\mathrm{kN})\end{array}$ & $\begin{array}{c}\mathrm{n}_{\mathrm{A}} \\
(\mathrm{rpm})\end{array}$ & $\begin{array}{c}\mathrm{T}_{\mathrm{A}}^{*} \\
(\mathrm{kN})\end{array}$ & $\begin{array}{c}\mathrm{Q}_{\mathrm{A}}^{\dagger} \\
(\mathrm{kNm})\end{array}$ & $\begin{array}{c}\mathrm{P}_{\mathrm{DI}} \\
(\mathrm{kW})\end{array}$ \\
\hline
\end{tabular}

$\begin{array}{llllll}0.00 & 424 & 104 & 530 & 132 & 2860 \\ 0.25 & 432 & 105 & 540 & 135 & 2955 \\ 0.50 & 443 & 106 & 554 & 139 & 3091 \\ 0.75 & 456 & 108 & 570 & 144 & 3252 \\ 1.00 & 471 & 110 & 589 & 149 & 3435 \\ 1.25 & 488 & 112 & 609 & 155 & 3639 \\ 1.50 & 505 & 115 & 631 & 161 & 3862 \\ 1.75 & 524 & 117 & 655 & 167 & 4106 \\ 2.00 & 543 & 120 & 679 & 174 & 4368 \\ 2.25 & 564 & 123 & 705 & 181 & 4650 \\ 2.50 & 586 & 125 & 732 & 189 & 4952 \\ 2.75 & 608 & 128 & 760 & 196 & 5273 \\ 3.00 & 631 & 131 & 789 & 204 & 5615 \\ 3.25 & 656 & 134 & 819 & 212 & 5976 \\ 3.50 & 680 & 138 & 851 & 221 & 6358 \\ 3.75 & 706 & 141 & 883 & 229 & 6761 \\ 4.00 & 733 & 144 & 916 & 238 & 7185 \\ 4.25 & 760 & 147 & 950 & 248 & 7630 \\ 4.50 & 787 & 150 & 984 & 257 & 8097 \\ 4.75 & 816 & 154 & 1020 & 266 & 8586 \\ 5.00 & 845 & 157 & 1056 & 276 & 9097 \\ 5.25 & 875 & 161 & 1094 & 286 & 9631 \\ 5.50 & 905 & 164 & 1132 & 297 & 10188 \\ 5.75 & 936 & 167 & 1171 & 307 & 10769 \\ 6.00 & 968 & 171 & 1210 & 318 & 11373\end{array}$

$\mathrm{h}_{\mathrm{i}}=0.70 \mathrm{~m}, \sigma=800 \mathrm{kPa}$

$$
\mathrm{h}_{\mathrm{i}}=0.45 \mathrm{~m}, \sigma=800 \mathrm{kPa}
$$

$\begin{array}{llrrrr}0.00 & 290 & 86 & 363 & 90 & 1618 \\ 0.25 & 295 & 87 & 368 & 92 & 1667 \\ 0.50 & 301 & 88 & 376 & 95 & 1736 \\ 0.75 & 309 & 89 & 386 & 98 & 1820 \\ 1.00 & 318 & 91 & 398 & 101 & 1917 \\ 1.25 & 328 & 93 & 410 & 105 & 2025 \\ 1.50 & 339 & 94 & 424 & 108 & 2146 \\ 1.75 & 351 & 97 & 438 & 113 & 2278 \\ 2.00 & 363 & 99 & 454 & 117 & 2422 \\ 2.25 & 376 & 101 & 471 & 122 & 2578 \\ 2.50 & 390 & 104 & 488 & 126 & 2746 \\ 2.75 & 405 & 106 & 506 & 131 & 2926 \\ 3.00 & 420 & 109 & 525 & 137 & 3118 \\ 3.25 & 436 & 112 & 545 & 142 & 3324 \\ 3.50 & 453 & 114 & 566 & 148 & 3542 \\ 3.75 & 470 & 117 & 587 & 154 & 3774 \\ 4.00 & 487 & 120 & 609 & 160 & 4019 \\ 4.25 & 506 & 123 & 632 & 166 & 4278 \\ 4.50 & 524 & 126 & 656 & 172 & 4551 \\ 4.75 & 544 & 129 & 680 & 179 & 4838 \\ 5.00 & 564 & 132 & 705 & 185 & 5140 \\ 5.25 & 584 & 135 & 730 & 192 & 5457 \\ 5.50 & 605 & 139 & 756 & 199 & 5789 \\ 5.75 & 626 & 142 & 783 & 207 & 6137 \\ 6.00 & 648 & 145 & 810 & 214 & 6501\end{array}$




\begin{tabular}{cccccc}
$\begin{array}{c}\mathrm{V} \\
(\mathrm{m} / \mathrm{s})\end{array}$ & $\begin{array}{c}\mathrm{R}_{\mathrm{it}} \\
(\mathrm{kN})\end{array}$ & $\begin{array}{c}\mathrm{n}_{\mathrm{A}} \\
(\mathrm{rpm})\end{array}$ & $\begin{array}{c}\mathrm{T}_{\mathrm{A}}{ }^{*} \\
(\mathrm{kN})\end{array}$ & $\begin{array}{c}\mathrm{Q}_{\mathrm{A}}^{\dagger} \\
(\mathrm{kNm})\end{array}$ & $\begin{array}{c}\mathrm{P}_{\mathrm{DI}}{ }^{* *} \\
(\mathrm{~kW})\end{array}$ \\
\hline
\end{tabular}

$\begin{array}{lrrrrr}0.00 & 252 & 80 & 316 & 78 & 1312 \\ 0.25 & 260 & 81 & 325 & 81 & 1383 \\ 0.50 & 271 & 83 & 339 & 85 & 1485 \\ 0.75 & 284 & 85 & 356 & 90 & 1609 \\ 1.00 & 299 & 88 & 374 & 95 & 1752 \\ 1.25 & 316 & 91 & 394 & 101 & 1913 \\ 1.50 & 333 & 94 & 416 & 107 & 2091 \\ 1.75 & 352 & 97 & 440 & 113 & 2288 \\ 2.00 & 371 & 100 & 464 & 120 & 2502 \\ 2.25 & 392 & 103 & 490 & 127 & 2735 \\ 2.50 & 414 & 107 & 517 & 134 & 2986 \\ 2.75 & 436 & 110 & 545 & 141 & 3256 \\ 3.00 & 460 & 113 & 574 & 149 & 3545 \\ 3.25 & 484 & 117 & 605 & 157 & 3854 \\ 3.50 & 509 & 121 & 636 & 166 & 4183 \\ 3.75 & 534 & 124 & 668 & 174 & 4532 \\ 4.00 & 561 & 128 & 701 & 183 & 4901 \\ 4.25 & 588 & 131 & 735 & 192 & 5292 \\ 4.50 & 616 & 135 & 769 & 202 & 5704 \\ 4.75 & 644 & 139 & 805 & 211 & 6138 \\ 5.00 & 673 & 143 & 842 & 221 & 6594 \\ 5.25 & 703 & 146 & 879 & 231 & 7073 \\ 5.50 & 733 & 150 & 917 & 241 & 7574 \\ 5.75 & 765 & 154 & 956 & 251 & 8099 \\ 6.00 & 796 & 158 & 995 & 262 & 8647\end{array}$

$\mathrm{h}_{i}=0.45 \mathrm{~m}, \sigma=400 \mathrm{kPa}$.

\begin{tabular}{llrrrr}
0.00 & 140 & 60 & 175 & 43 & 540 \\
0.25 & 144 & 61 & 180 & 45 & 571 \\
0.50 & 151 & 62 & 188 & 47 & 618 \\
0.75 & 158 & 64 & 198 & 50 & 675 \\
1.00 & 167 & 66 & 209 & 53 & 743 \\
1.25 & 177 & 69 & 222 & 57 & 820 \\
1.50 & 188 & 71 & 235 & 61 & 908 \\
1.75 & 200 & 74 & 250 & 65 & 1005 \\
2.00 & 213 & 77 & 266 & 69 & 1113 \\
2.25 & 226 & 80 & 282 & 74 & 1232 \\
2.50 & 240 & 83 & 300 & 78 & 1362 \\
2.75 & 254 & 86 & 318 & 83 & 1503 \\
3.00 & 270 & 90 & 337 & 88 & 1656 \\
3.25 & 286 & 93 & 357 & 94 & 1821 \\
3.50 & 302 & 96 & 378 & 99 & 1999 \\
3.75 & 319 & 100 & 399 & 105 & 2189 \\
4.00 & 337 & 103 & 421 & 111 & 2392 \\
4.25 & 355 & 106 & 444 & 117 & 2609 \\
4.50 & 374 & 110 & 467 & 123 & 2839 \\
4.75 & 393 & 113 & 492 & 130 & 3083 \\
5.00 & 413 & 117 & 516 & 137 & 3342 \\
5.25 & 433 & 120 & 542 & 143 & 3615 \\
5.50 & 454 & 124 & 568 & 150 & 3903 \\
5.75 & 476 & 127 & 595 & 158 & 4207 \\
6.00 & 498 & 131 & 622 & 165 & 4526 \\
\hline \multirow{2}{*}{ Total thrust. } & & & & \\
†Torque per propeller. & & & \\
$* *$ Total delivered power. & & & &
\end{tabular}

